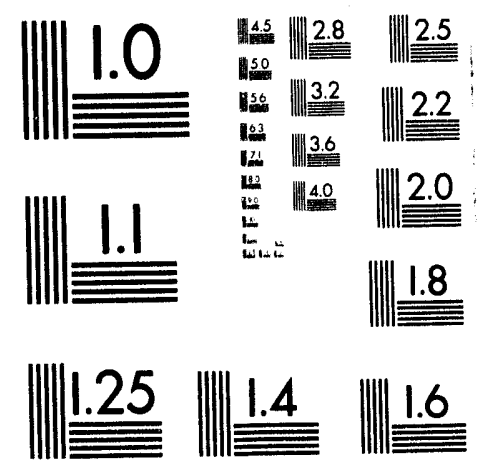



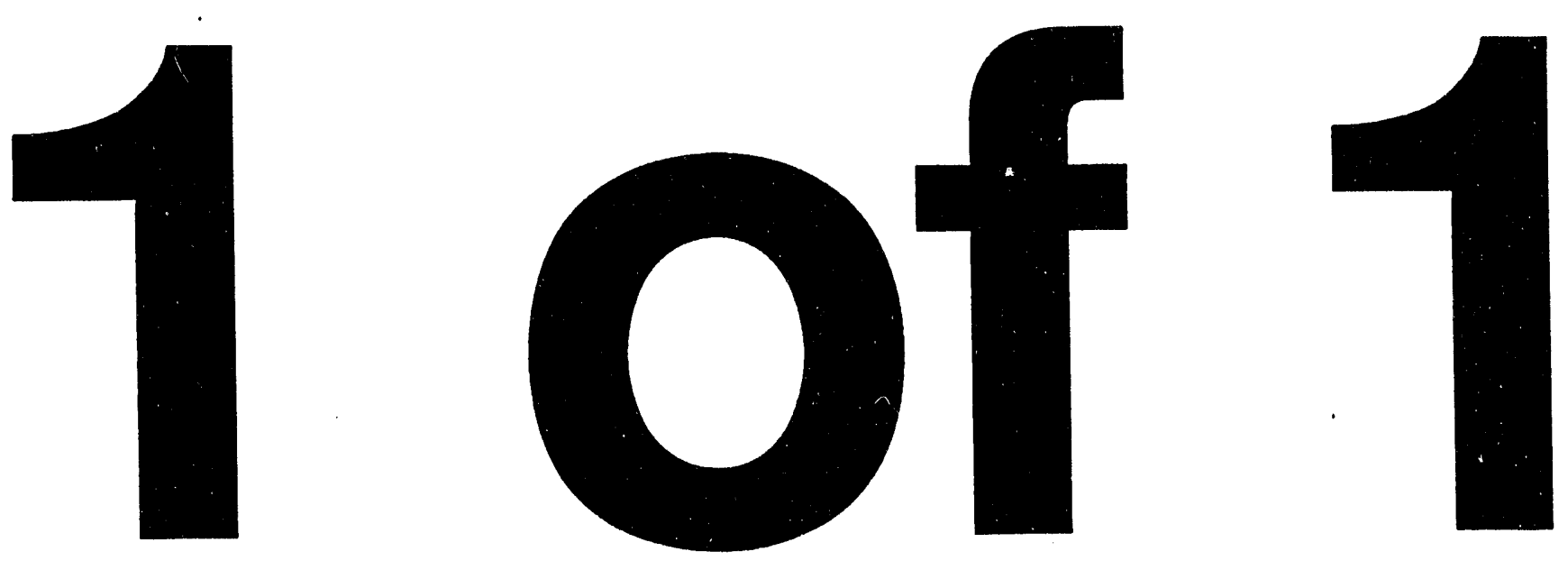


\title{
Model for Heat-Up of Structures in VICTORIA
}

\author{
N. E. Bixler \\ Severe Accident Phenomenology Department \\ Sandia National Laboratories \\ Albuquerque, NM 87185-1137
}

\begin{abstract}
VICTORIA is a mechanistic computer code that treats fission product behavior in the reactor coolant system during a severe accident. During an accident, fission products that deposit on structural surfaces produce heat loads that can cause fission products to revaporize and possibly cause structures, such as a pipe, to fail. This mechanism had been lacking from the VICTORIA model. This report describes the structural heat-up model that has recently been implemented in the code.

A sample problem shows that revaporization of fission products can occur as structures heat up due to radioactive decay. In the sample problem, the mass of deposited fission products reaches a maximum, then diminishes. Similarly, temperatures of the deposited film and adjoining structure reach a maximum, then diminish.
\end{abstract}




\section{Contents}

Acknowledgments

vi

\section{Model for Heat-Up of Structures in VICTORIA}

1. Introduction ..........................................................................................

2. Assumptions and Mathematical Model ................................................ 2

3. Data Internal to Code ........................................................................... 8

4. Additional Input Data............................................................................. 10

5. Practical Aspects of the Model Implementation ...................................... 12

6. Data Available for Validation .............................................................. 12

7. Sample Calculation ........................................................................ 13

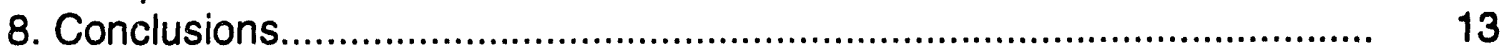

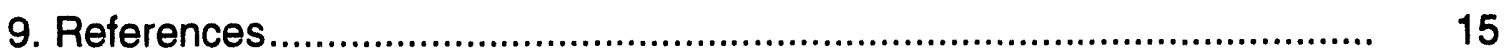

Appendix A.1-Sample Problem Input File ........................................... A-1

Appendix A.2-Sample Problem Output File ........................................ A-7

\section{Figures}

Figure 1. Schematic of the heat fluxes used in Equations 1 and 2

Figure 2. Transient behavior of deposited fission products (only those in Tables 2 and 3 ) in Cell 8

Figure 3. Transient behavior of film and structure temperatures.

\section{Tables}

Table 1. Density, heat capacity, and thermal conductivity evaluated at $700 \mathrm{~K}$ for four structural materials and for the deposited film

Table 2. Normalized decay powers $\left(W / \mathrm{kW}_{\mathrm{th}}\right)$ as a function of elapsed time since reactor SCRAM (s)

Table 3. Normalized decay powers $\left(\mathrm{W} / \mathrm{kW}_{\mathrm{th}}\right)$ as a function of elapsed time since reactor SCRAM (hr) 


\section{Acknowledgments}

The author wishes to thank D. A. Powers and T. J. Heames for their helpful comments. Thanks also go to the United States Nuclear Regulatory Commission for their support of this work through FIN A1837. 


\section{Introduction}

VICTORIA [1] is a mechanistic computer code that treats fission product behavior in the reactor coolant system (RCS) during a severe accident. It models release of fission products from fuel rods, transport within the RCS, chemical interactions, and aerosol physics. The heart of VICTORIA is its relatively sophisticated chemistry package, which currently models the equilibrium of 288 species composed of 26 elements. It also has a state-of-the-art aerosol physics package, which models condensation/evaporation from aerosol surfaces, agglomeration, deposition, and resuspension. VICTORIA does not model thermal-hydraulics for the RCS; rather, these data are required as part of the input to the program.

During a reactor accident, vapors and aerosols, which contain fission products, generally deposit onto structural surfaces. One consequence of such deposition is that decay heating due to radioactive decay of the fission products may cause structures to heat up. This heat-up may induce some revaporization of the deposited material and, in severe cases, may lead to failure of the structure. Revaporization of deposited fission products is a chief concern in the late stages of an accident when the reactor containment is likely to have failed, or alternatively, in the event of an accident in which containment is bypassed. If the containment has failed or bypassed, there is a direct path for fission products that are left in the RCS to reach the environment. Revaporization is the primary mechanism by which this can occur.

The current version of VICTORIA does account for vapor condensation and aerosol deposition onto structural surfaces. However, it does not analyze the amount of decay heat produced by the deposited radionuclides, nor does it couple the heat produced by decay heating with local temperatures. This report describes a new model to incorporate the effect of decay heating on thermal response in a simple way.

Data are generally available for the decay heat produced per mass of an isotope [2]. Data on the relative abundances of isotopes in a normally operating nuclear reactor are also available [3]. These data have been combined to describe the amount of decay heat per mass of each element as a function of time after reactor shutdown [4]. This information is the basis used here to prescribe the heat source resulting in the local heat-up of structures due to decay heating of deposited fission products.

Additional heat transfer information is needed to describe the transient thermal conditions caused by decay heating on a structure. These include density, heat capacity, and thermal conductivity of the condensate film and of the structure upon which it resides, thermal conductivity of the insulation surrounding the structure, the ambient temperature in the containment, a heat transfer coefficient for heat losses to gas flowing within the structure, and the temperature of that gas. Many of these parameters must be prescribed, either explicitly or implicitly, as part of the 
input data. However, much of the information needed to calculate the heat transfer to the gas is already embedded within VICTORIA.

With all of the relevant heat transfer parameters prescribed, the transient thermal response of the structure can be determined. If the structure exceeds a failure temperature, the geometry and response of the reactor coolant system (RCS) would undergo an abrupt change. Thus, it would make no sense to continue the analysis using the original geometry and flow conditions. Instead, the calculation is stopped in order to allow the user to restart the calculation with a different geometry and set of thermal-hydraulic conditions.

The following sections describe the mathematical model and implicit assumptions used to determine the thermal response of a structure containing deposited fission products, the data that are needed to perform the analysis, some practical aspects of the model, a sample calculation using the new model, and conclusions.

\section{Assumptions and Mathematical Model}

Several simplifying assumptions are made in the mathematical model described below and in the implementation of this model in VICTORIA. The major assumptions are as follows:

1. All isotopes of an element have the same diffusive and transport properties. Thus, the relative abundance of isotopes is the same everywhere in the RCS. This allows local decay heating to be determined as a function of the mass of each element (rather than the mass of each isotope) that has been deposited and the elapsed time since reactor shutdown.

2. Heat generated by gamma radiation is deposited within the surface film. Obviously, in many cases this is a bad assumption, but to determine where gamma radiation would be deposited is extremely complicated in all but the simplest of domains. While an overall recirculatory flow may exist in the RCS, recirculation does not occur within an individual cell. In other words, flow is unidirectional in all pipes and channels where decay heating occurs. This facilitates estimation of heat transfer conditions.

3. A uniform temperature exists within the structure. Likewise, a uniform temperature exists in the deposited fission product film.

4. Thermal conductivity of the insulation and thermal properties of the structure and film are independent of temperature.

5. The ambient temperature outside the exiernal surface of the structure is constant. 
6. Heat transfer to the gas has a negligible effect on the gas temperature. This implies that the throughput of thermal mass is great enough so that heat losses to the structure are negligible.

7. Radiation between the gas and the structure film is taken to be negligible. This is generally a good assumption unless the opacity of the gas is large due to suspended aerosol particles.

Some of these assumptions, especially those involving constant properties, could easily be eliminated. However, the benefit of keeping the input requirements and additional coding simple is viewed to outweigh the benefit of additional generality of the model.

The respective equations for modeling heat-up of the deposited film and structure are

$$
\begin{gathered}
\varepsilon \rho_{F} C p_{F} \frac{\partial T_{F}}{\partial t}=Q-L_{1}-L_{2} \text { and } \\
w \rho_{S} C p_{S \frac{\partial t}{\partial t}} T_{S}=L_{2}-L_{3} .
\end{gathered}
$$

Here, $\varepsilon$ is the thickness of the structural film, $w$ is the wall thickness of the structure, $\rho$ is density, $C p$ is heat capacity, $T$ is temperature, $t$ is time, $Q$ is the rate of heat generation per unit area due to decay heating within the deposited film, $L_{1}$ is the heat flux to the gas flowing within the structure, $L_{2}$ is the heat flux from the surface film to the adjacent structure, and $L_{3}$ is the heat flux through a possible insulating layer surrounding the structure to the ambient. The subscript $F$ indicates a film property and the subscript $S$ indicates a structural property. Each of the fluxes are based on the surface area of the inside of the structure and are illustrated in Figure 1.

The rate of heat generation due to decay heating is

$$
Q=\varepsilon \sum_{j} q_{j}(t) M_{j} \sum_{i} a_{j i} n_{i}
$$

Here, the first summation is over the set of elements and the second is over the set of species. $q_{j}(t)$ is the rate of heat generation by atomic decay per unit mass of element, $j$, as a function of time, and $a_{j i}$ is the number of moles of element, $j$, contained in one mole of species, $i$. The data used for $q_{j}(t)$ are discussed in Section 3 below. 


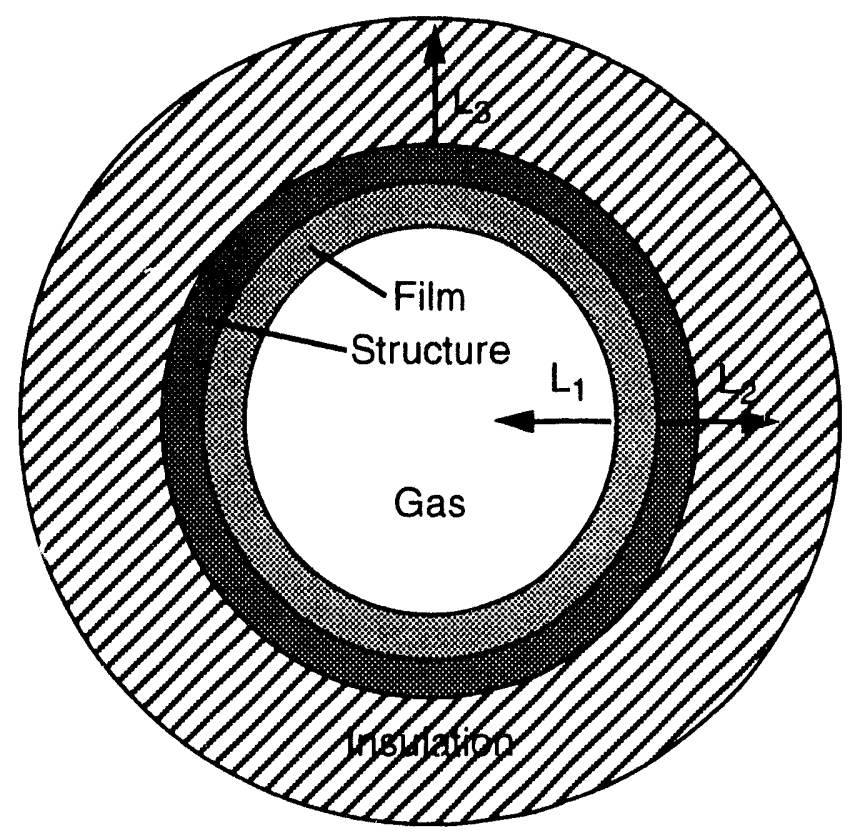

Figure 1. Schematic of the heat fluxes used in Equations 1 and 2

The heat loss to the flowing gas within the structure is

$$
L_{1}=h_{1}\left(T_{F}-T_{G}\right)
$$

Here, $h_{1}$ is a heat transfer coefficient that depends on thermal and geometric properties of the structure and $T_{G}$ is the temperature in the gas. If the heat transfer is at a radial surface, then the following definition applies (see, e.g., [5]):

$$
h_{1}=\frac{1}{\log \left(\frac{r_{i S}-\varepsilon}{r_{i S}-\varepsilon-\delta}\right) \frac{r_{i S}}{k_{G}}+\log \left(\frac{2 r_{i S}-\varepsilon}{2 r_{i S}-2 \varepsilon}\right) \frac{r_{i S}}{k_{F}}} \text {; }
$$

otherwise, if the heat transfer is along an axial surface (modeled as a flat plate), then

$$
h_{1}=\frac{1}{\frac{\delta}{k_{G}}+\frac{\varepsilon}{2 k_{F}}}
$$


Here, $r_{i s}$ is the inner radius of the structure, $k_{g}$ is the thermal conductivity of the gas and $\delta$ is the thermal boundary layer thickness in the gas.

The heat loss from the film to the structure is

$$
L_{2}=h_{2}\left(T_{F}-T_{S}\right)
$$

Here, $h_{2}$ is the heat transfer coefficient between the film and the structural material. On radial surfaces, it is

$$
h_{2}=\frac{1}{\log \left(\frac{2 r_{i S}}{2 r_{i S}-\varepsilon}\right) \frac{r_{i S}}{k_{F}}+\log \left(\frac{r_{i S}+r_{o S}}{2 r_{i S}}\right) \frac{r_{i S}}{k_{S}}} \text {; }
$$

on axial surfaces, it is

$$
h_{2}=\frac{1}{\frac{\varepsilon}{2 k_{F}}+\frac{\Delta z_{S}}{2 k_{S}}} \text {. }
$$

Here, $r_{o s}$ is the outer radius of the structure and $\Delta z_{S}$ is the axial thickness of the structure.

Finally, the heat loss through the structural insulation is

$$
L_{3}=h_{3}\left(T_{S}-T_{A}\right)
$$

On a radial surface, $h_{3}$ is

$$
h_{3}=\frac{1}{\log \left(\frac{r_{I}}{r_{o S}}\right) \frac{r_{i S}}{k_{I}}+\log \left(\frac{2 r_{o S}}{r_{o S}+r_{i S}}\right) \frac{r_{i S}}{k_{S}}} \text {; }
$$

on an axial surface it is

$$
h_{3}=\frac{1}{\frac{\Delta z_{l}}{k_{l}}+\frac{\Delta z_{S}}{2 k_{S}}} \text {. }
$$




\section{Assumptions and Mathematical Model}

Here, $\Delta z_{l}$ is the axial thickness of the insulation, $k_{l}$ is the thermal conductivity of the insulation, $T_{S}$ is the temperature of the structure, $T_{A}$ is the ambient temperature external to the structure, and $r_{i}$ is the outer radius of the insulation.

Equations (1)-(4), (7), and (10), along with definitions of the heat transfer coefficients in (5), (6), (8), (9), (11), and (12), form a complete set of equations to describe the heat-up of a surface film and underlying structure. Normally, these equations would be solved numerically at each time step. However, explicit implementation of these equations proved to be unstable. The reason for this is that the initial mass of the film is very small, and thus its thermal mass is very small. Heat transfer to or from the gas or heat generation due to decay heating can cause substantial changes in temperature in the film over a single time step. There are three alternatives to the explicit implementation: (1) an implicit numerical implementation; (2) a numerical procedure using a sub-interval time step; and (3) an analytic solution of the equations. The third alternative was chosen because it is the most efficient and the most robust of the available choices.

Equations (1)-(4), (7), and (10) form a set of two coupled ordinary differential equations, which can be solved by standard methods. The solution has the following form:

$$
\begin{aligned}
& T_{F}=c_{1} e^{r_{1} t}+c_{2} e^{r_{2} t}+d_{1}, \\
& T_{S}=c_{3} e^{r_{1} t}+c_{4} e^{r_{2} t}+d_{2} .
\end{aligned}
$$

The exponents in Equations (13) and (14) are defined as follows:

$$
r_{1,2}=\frac{-\left(h_{1}^{\prime}+h_{2}^{\prime}+h_{2}^{\prime \prime}+h_{3}^{\prime}\right) \pm \sqrt{\left[h_{1}^{\prime}+h_{2}^{\prime}-h_{2}^{\prime \prime}-h_{3}^{\prime}\right]^{2}+4 h_{2}^{\prime} h_{2}^{\prime \prime}}}{2} .
$$

Here, the subscripts 1 and 2 refer to the plus and minus, respectively, and the primed quantities are related to the heat transfer coefficients defined above as follows:

$$
\begin{aligned}
& h_{1}^{\prime}=\frac{h_{2}}{\varepsilon \rho_{F} C p_{F}} \\
& h_{2}^{\prime}=\frac{h_{2}}{\varepsilon \rho_{F} C p_{F}}
\end{aligned}
$$




$$
\begin{aligned}
h_{2}^{\prime \prime} & =\frac{h_{2}}{w \rho_{S} C p_{S}} \\
h_{3}^{\prime} & =\frac{h_{3}}{w \rho_{S} C p_{S}}
\end{aligned}
$$

The coefficients in Equations (13) and (14) are defined as follows:

$$
\begin{gathered}
c_{1}=\frac{h_{2}^{\prime}\left[T_{S}\left(t^{n}\right)-d_{2}\right]-\left(r_{2}+h_{1}^{\prime}+h_{2}^{\prime}\right)\left[T_{F}\left(t^{n}\right)-d_{1}\right]}{\sqrt{\left[h_{1}^{\prime}+h_{2}^{\prime}-h_{2}^{\prime \prime}-h_{3}^{\prime}\right]^{2}+4 h_{2}^{\prime} h_{2}^{\prime \prime}}} ; \\
c_{2}=\frac{-h_{2}^{\prime}\left[T_{S}\left(t^{n}\right)-d_{2}\right]+\left(r_{1}+h_{1}^{\prime}+h_{2}^{\prime}\right)\left[T_{F}\left(t^{n}\right)-d_{1}\right]}{\sqrt{\left[h_{1}^{\prime}+h_{2}^{\prime}-h_{2}^{\prime \prime}-h_{3}^{\prime}\right]^{2}+4 h_{2}^{\prime} h_{2}^{\prime \prime}}} ; \\
c_{3}=\frac{r_{1}+h_{1}^{\prime}+h_{2}^{\prime}}{h_{2}^{\prime}} c_{1} ; \\
d_{1}=\frac{\left(h_{2}^{\prime \prime}+h_{3}^{\prime}\right)\left(Q^{\prime}+h_{1}^{\prime} T_{G}\right)+h_{2}^{\prime} h_{3}^{\prime} T_{A}}{h_{1}^{\prime} h_{2}^{\prime \prime}+h_{1}^{\prime} h_{3}^{\prime}+h_{2}^{\prime} h_{3}^{\prime}} ; \text { and } \\
c_{2}=\frac{r_{2}+h_{1}^{\prime}+h_{2}^{\prime}}{h_{2}^{\prime}} c_{2} ; \\
d_{2}=\frac{h_{2}^{\prime \prime}\left(Q^{\prime}+h_{1}^{\prime} T_{G}\right)+\left(h_{1}^{\prime}+h_{2}^{\prime}\right) h_{3}^{\prime} T_{A}}{h_{1}^{\prime} h_{2}^{\prime \prime}+h_{1}^{\prime} h_{3}^{\prime}+h_{2}^{\prime} h_{3}^{\prime}} .
\end{gathered}
$$

Here, $T_{F}\left(t^{n}\right)$ and $T_{S}\left(t^{n}\right)$ refer respectively to the film and structure temperatures at the beginning of a time step (in essence, the initial conditions) and

$$
Q^{\prime}=\frac{h_{2}}{\varepsilon \rho_{F} C p_{F}} .
$$




\section{Data Internal to the Code}

Some of the parameters that appear in Equations (1) through (5) are given in data statements or are evaluated within the code; others must be prescribed by the user for each problem. This section describes the parameters that are defined within the code. Section 4 describes the additional input data needed for this model. The parameters are discussed in the order that they appear in the equations.

Table 1. Density, heat capacity, and thermal conductivity evaluated at $700 \mathrm{~K}$ for four structural materials and for the deposited film

\begin{tabular}{c|cccc}
\hline Number & Name & $\begin{array}{c}\text { Density } \\
\left(\mathrm{kg} / \mathrm{m}^{3}\right)\end{array}$ & $\begin{array}{c}\text { Heat Capacity } \\
(\mathrm{J} / \mathrm{kgK})\end{array}$ & $\begin{array}{c}\text { Thermal } \\
\text { Conductivity } \\
(\mathrm{W} / \mathrm{mK})\end{array}$ \\
\hline 1 & Zircaloy-4 [6] & 6550 & 340 & 18 \\
2 & Inconel 600 [7] & 8420 & 900 & 15 \\
3 & Stainless Steol [7] & 7930 & 800 & 15 \\
4 & Inert $\left(\mathrm{ZrO}_{2}\right)[6]$ & 5700 & 570 & 1.7 \\
& Film $\left(\mathrm{Fe}_{2} \mathrm{O}_{3}\right)[6]$ & & 950 & 3.4 \\
\hline \hline
\end{tabular}

The thickness of the structural film, $\varepsilon$, in Equations (1) and (3) is defined in a data statement to be $0.5 \mathrm{~mm}$ [1]. Molar concentrations of species, $n_{i}$, which appear in Equation (3), are determined as part of the solution of thermodynamic equilibrium. Molecular weights of the species, $M_{i}$, which appear in Equation (2), are calculated within the code from the atomic weights of the elements, $M_{i}$, and from the coefficients, $a_{j i}$, which appear in Equation (3) and are defined in data statements. Densities, $\rho$, heat capacities, $C p$, and thermal conductivities, $k$, of the film and structural materials are defined in data statements within the code. Their values are given in Table 1.

Values are tabulated in [4] for 29 elements that produce more than $99 \%$ of the decay heat in a LWR for the first two days after reactor shutdown. Only a subset of these elements are represented in VICTORIA. Data from [4] were extracted for each fission product in VICTORIA and for times after reactor shuidown from 0 to 20 hours. The values used in the code are reported in Tables 2 and 3.

Two points concerning Tables 2 and 3 are noteworthy. First, the data represent not only decay heat produced by the parent radionuclide, but also by daughters, granddaughters, etc. This is appropriate for VICTORIA since no explicit accounting of decay chains is performed. This also accounts for the fact that some of the data in the table do not decrease monotonically with time. Second, the data have been 
Table 2. Normalized decay powers $\left(W / k W_{t h}\right)$ as a function of elapsed time since reactor SCRAM (s)

\begin{tabular}{c|cccccccccc} 
Time & 0 & 6 & 12 & 18 & 30 & 60 & 120 & 240 & 600 & 1200 \\
\hline Element & & & & & & & & & & \\
Cs & 4.4 & 3.2 & 3.2 & 2.9 & 2.8 & 2.3 & 1.9 & 1.6 & 1.2 & 0.91 \\
I & 4.7 & 4.1 & 4.2 & 3.8 & 3.5 & 3.3 & 2.9 & 2.8 & 2.6 & 2.4 \\
Ba & 2.6 & 2.2 & 2.0 & 1.8 & 1.6 & 1.4 & 1.3 & 1.2 & 1.0 & 0.79 \\
Sr & 3.4 & 2.6 & 2.4 & 2.3 & 2.1 & 1.8 & 1.5 & 1.3 & 1.1 & 0.88 \\
Zr & 2.3 & 2.5 & 2.1 & 1.8 & 1.3 & 0.91 & 0.70 & 0.64 & 0.67 & 0.67 \\
Sn & 0.44 & 0.38 & 0.35 & 0.35 & 0.32 & 0.29 & 0.23 & 0.17 & 0.12 & 0.10 \\
To & 2.1 & 1.8 & 1.7 & 1.6 & 1.4 & 1.3 & 1.2 & 1.1 & 1.1 & 1.0 \\
U & 1.2 & 1.2 & 1.2 & 1.2 & 1.2 & 1.2 & 1.2 & 1.1 & 0.91 & 0.70 \\
Kr & 2.4 & 1.9 & 1.7 & 1.6 & 1.5 & 1.3 & 1.1 & 0.97 & 0.79 & 0.76 \\
Xo & 2.4 & 2.1 & 1.9 & 1.8 & 1.7 & 1.5 & 1.2 & 0.94 & 0.70 & 0.53 \\
\hline Mo & 1.9 & 2.1 & 2.1 & 2.1 & 2.0 & 1.8 & 1.5 & 1.2 & 0.85 & 0.61 \\
\hline Ru & 0.53 & 0.53 & 0.56 & 0.56 & 0.59 & 0.59 & 0.56 & 0.50 & 0.44 & 0.38 \\
\hline Sb & 1.8 & 1.6 & 1.6 & 1.5 & 1.5 & 1.4 & 1.2 & 1.0 & 0.67 & 0.50 \\
\hline \hline
\end{tabular}

normalized by decay power prior to reactor SCRAM. The rationale for this normalization stems from the following assertions that are made in [4]:

1. Unstable isotopes of fission products reach steady concentration levels within a few days after reactor start-up and remain level during normal reactor operation. These levels are insensitive to time during the annual operating cycle, the type of reactor (i.e., PWR versus BWR), or issues of fuel management history.

2. Stable isotopes gradually build up during the annual operating cycle. Their concentrations are sensitive to fuel management history and type of reactor.

3. Inventories of unstable isotopes of fission products depend mainly on operating power prior to reactor shutdown, provided that reactor power was held level long enough for a steady state to be achieved. 
Additional Input Data

Table 3. Normalized decay powers $\left(W / \mathrm{KW}_{\mathrm{th}}\right)$ as a function of elapsed time since reactor SCRAM (hr)

\begin{tabular}{c|cccccccccc}
\hline Time & 1 & 1.5 & 2 & 4 & 6 & 8 & 10 & 12 & 15 & 20 \\
\hline Element & & & & & & & & & & \\
Cs & 0.38 & 0.23 & 0.15 & 0.07 & 0.06 & 0.06 & 0.06 & 0.06 & 0.06 & 0.06 \\
I & 1.9 & 1.6 & 1.5 & 1.0 & 0.82 & 0.70 & 0.62 & 0.53 & 0.47 & 0.38 \\
Ba & 0.47 & 0.38 & 0.35 & 0.27 & 0.25 & 0.26 & 0.27 & 0.29 & 0.32 & 0.35 \\
Sr & 0.76 & 0.73 & 0.70 & 0.62 & 0.53 & 0.44 & 0.39 & 0.32 & 0.27 & 0.21 \\
Zr & 0.73 & 0.79 & 0.79 & 0.82 & 0.79 & 0.76 & 0.70 & 0.67 & 0.62 & 0.56 \\
Sn & 0.07 & 0.05 & 0.04 & 0.01 & 0.007 & 0.004 & 0.004 & 0.003 & 0.003 & 0.003 \\
To & 0.85 & 0.79 & 0.76 & 0.64 & 0.64 & 0.64 & 0.64 & 0.64 & 0.64 & 0.62 \\
U & 0.22 & 0.10 & 0.05 & 0.02 & 0.02 & 0.02 & 0.02 & 0.02 & 0.02 & 0.02 \\
Kr & 0.70 & 0.62 & 0.53 & 0.32 & 0.18 & 0.11 & 0.07 & 0.04 & 0.02 & 0.01 \\
Xe & 0.29 & 0.20 & 0.15 & 0.09 & 0.08 & 0.08 & 0.07 & 0.07 & 0.07 & 0.06 \\
Mo & 0.25 & 0.19 & 0.17 & 0.17 & 0.17 & 0.17 & 0.17 & 0.17 & 0.17 & 0.16 \\
Ru & 0.35 & 0.35 & 0.32 & 0.29 & 0.28 & 0.26 & 0.25 & 0.23 & 0.23 & 0.22 \\
Sb & 0.26 & 0.18 & 0.13 & 0.08 & 0.06 & 0.05 & 0.04 & 0.03 & 0.03 & 0.02 \\
\hline \hline
\end{tabular}

It follows that the data in Table 2 must be scaled according to reactor power prior to shutdown and according to the abundances of each of the fission products. The the manner in which these scalings are performed is described in Section 5 below.

\section{Additional Input Data}

Equations (1) through (5) use a number of parameters that are not currently available, either as part of the input or part of the internal data in VICTORIA. Some of these parameters, plus some information to tell VICTORIA where heat-up calculations are to be performed, must be included in the input file. The additional data needed to run the decay heat and structure heat-up calculations are discussed in this section. 
Keeping with the current modular style of VICTORIA [1], heat-up of structures is treated as a new module named HEATUP. Thus the first input parameter that is required is a flag to tell the code whether or not heat-up calculations are to be included in the analysis. If the flag is set to zero, no decay heating calculations will be performed; if it is set to one, decay heating calculations will be performed; if it set to two, decay heating and coupling between decay heating and local temperatures are both calculated.

When this flag is set to 1 or 2 , some additional input data are expected by the code. When flag is set to 1 , one additional line of data is required following the thermalhydraulic input section. This line consists of four parameters: the ambient temperature inside containment, in units of K; elapsed time from reactor SCRAM to $t=0$ for the VICTORIA calculation, in units of $s$; the mass of uranium per unit of thermal energy produced by the reactor just prior to reactor SCRAM, in units of $\mathrm{kg}$ uranium per $\mathrm{kW}$ thermal; and structure failure temperature, in units of $\mathrm{K}$. Only the second and third of these parameters are used in the code when the decay heat flag is set to 1; all of them are used when it is set to 2. Guidance on the selection of appropriate values for structure failure temperatures is provided in [8].

Additional data are needed when the decay heat flag is set to 2. A flag array must be set to tell the code in which volumes to perform heat-up calculations. Usually heat-up calculations are needed in only a few of the volumes. Because of the thermal models that are used to determine heat losses to the ambient and to the gas flowing within the structure, heat-up of structures is allowed only along the perimeter of the domain. Thus the data needed for this and the following arrays should have as many values as the problem has perimeter cell edges (the data structure is the same as for boundary conditions [1]).

Structural materials, such as the those that are being considered here, can be specified to be made up of Zr-4, Inconel-600, 304 stainless steel, or inert material. The choice is specified by the structure identification flags that are part of the existing input file [1]. The choice of material will affect the heat capacity and density of the structural surface, as shown in Table 1. Although it is possible to select $\mathrm{Zr}-4$ as a material on the perimeter of the domain, it is not recommended when performing heat-up calculations with this material for reasons explained below.

Three additional pieces of data are required at each perimeter cell edge. These are the thickness of the structural wall, $w$, expressed in $\mathrm{m}$; the thermal conductivity of the insulation, $k_{i}$, in $\mathrm{W} / \mathrm{mK}$; and the insulation thickness in $\mathrm{m}$.

All of the data needed to calculate the losses to the flowing gas, defined in (5), are already embedded within the code. 


\section{Practical Aspects of the Model Implementation}

As mentioned in Section 3 above, the data in Table 2 need to be scaled before they can be used to calculate decay heating. This scaling is done in two parts. First the thermal power of the reactor prior to shutdown is calculated by taking the ratio of the mass of uranium initially in the fuel to the parameter defining the mass of uranium needed to generate a unit of thermal power. From this, the amount of decay heat produced by each fission product listed in Table 2 can be calculated. The second part of the scaling is simply to convert the total amount of decay heat produced by an element to that produced per unit mass. This is done by dividing the total decay heat produced by an element by its initial mass in the fuel. This tacitly makes the assumption that all fission products start out in the fuel at the beginning of a calculation. Once the data are scaled for the current problem, they are interpolated logarithmically to determine decay heat as a function of time.

Typical values for the amount of mass needed to produce a unit of thermal energy during normal power plant operation are $26 \times 10^{-3} \mathrm{~kg} / \mathrm{kW}$ for a PWR and $38 \times 10^{-3}$ $\mathrm{kg} / \mathrm{kW}$ for a BWR. However, if the plant is not operating normally prior to reactor shutdown, these values should be scaled to reflect the percent of capacity prior to shutdown.

Although there are four choices of structural materials, it is not advisable to perform heat-up calculations for structures made of Zircalloy-4. The problem is that both $\mathrm{Zr}$ and Sn, which are the main elements in Zircalloy-4, produce decay heat. VICTORIA has no mechanism for tracing the origin of an element and thus, does not distinguish between $\mathrm{Zr}$ and $\mathrm{Sn}$ that originated in the fuel and that which originated in the structure. This problem does not arise for the other three materials since they do not contain elements that produce decay heat.

When the decay heat flag is not set to 2, thermal transients for structures are determined by interpolating data from the input file. When the decay heating flag is set to 2 , only the initial temperature is taken from the input file for the cells which where decay heating is calculated. Afterward, Equations (1) and (2) are used to calculate the transient thermal response of the film and structure.

As mentioned above, the calculation is stopped if the user specified structure failure temperature is reached. The reasoning for this is that the geometry and thermal-hydraulics would likely change dramatically at this point, so continuation of the calculation would probably not make sense. However, the user can overcome this feature by simply setting the failure temperature to be artificially high.

\section{Data Available for Validation}

To the best of the author's knowledge, no data are available to validate this model. 


\section{Sample Calculation}

The sample calculation given here is primarily intended as an exercise to show the effects of decay heating in the context of a simple problem. It is based on the PHEBUS test bundle for FPT-0, which contains 21 trace irradiated fuel rods. The sample problem uses a total of eight cells with only one radial ring. The bottom five cells contain the fuel bundle; the top three consist of a conically shaped thermal gradient tube. Aerosols are injected just above the top of the fuel bundle to represent the presence of control rods, which are not explicitly modeled. For this test problem, the parameter specifying the mass of $U$ needed to produce a kilowatt of heat has been chosen to be artificially low. This has been done in order to compensate for the small mass of fission products that are released by the test bundle. The amount of decay heat produced in this case is great enough to revaporize some of the deposited fission products. Coupling between decay heating and local thermal response is only activated in the upper three cells.

Appendix A.1 contains a complete input file and Appendix A.2 contains a partial output file for the sample problem. Notice that six elements have been edited out of the element masses portion of the output file since these elements did not exist in this calculation.

Release of fission products from the fuel occurs at $3000 \mathrm{~s}$ (which is the initial time of the calculation). Accumulated deposition of fission products reaches a maximum at about $3400 \mathrm{~s}$, as shown in Figure 2. After this time, revaporization of the deposited fission products outstrips further deposition. Temperatures of the film and structure, on the other hand, reach a peak of $1099 \mathrm{~K}$ (for cell eight) at a later time, about $3800 \mathrm{~s}$, as shown in Figure 3. Afterwards, the temperature begins to fall because both the mass and heat output of deposited fission products diminishes.

Notice that a section describing temperatures (fuel, gas, and structure) and gas pressure has been added to the output. This is especially useful for the film and structure temperatures since they can not be determined by interpolating input data when the structure heat-up model is active.

\section{Conclusions}

A simple model for decay heat and its effect on thermal transients of structures has been incorporated into VICTORIA. This model implicitly accounts for decay heating due to parents, daughters, granddaughters, etc., but does not explicitly account for decay chains. Heat losses are calculated to the ambient surroundings and to the gas flowing within the structure.

The sample problem in Section 7 illustrates the use of the structure heat-up model. In that problem, both mass of deposited radionuclides and temperature reach a 


\section{Conclusions}

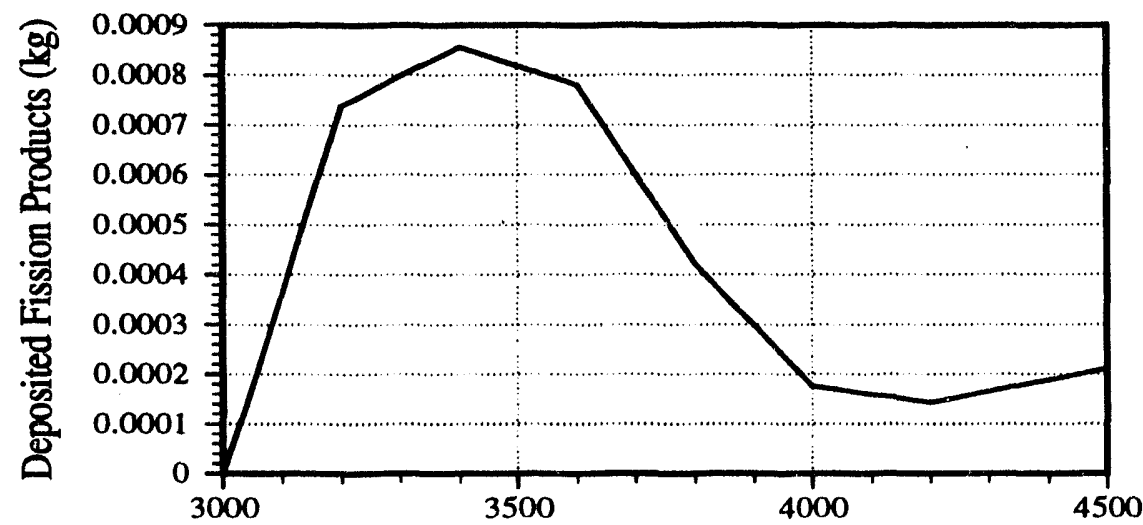

Time (s)

Figure 2. Transient behavior of deposited fission products (only those in Tables 2 and 3 ) in Cell 8

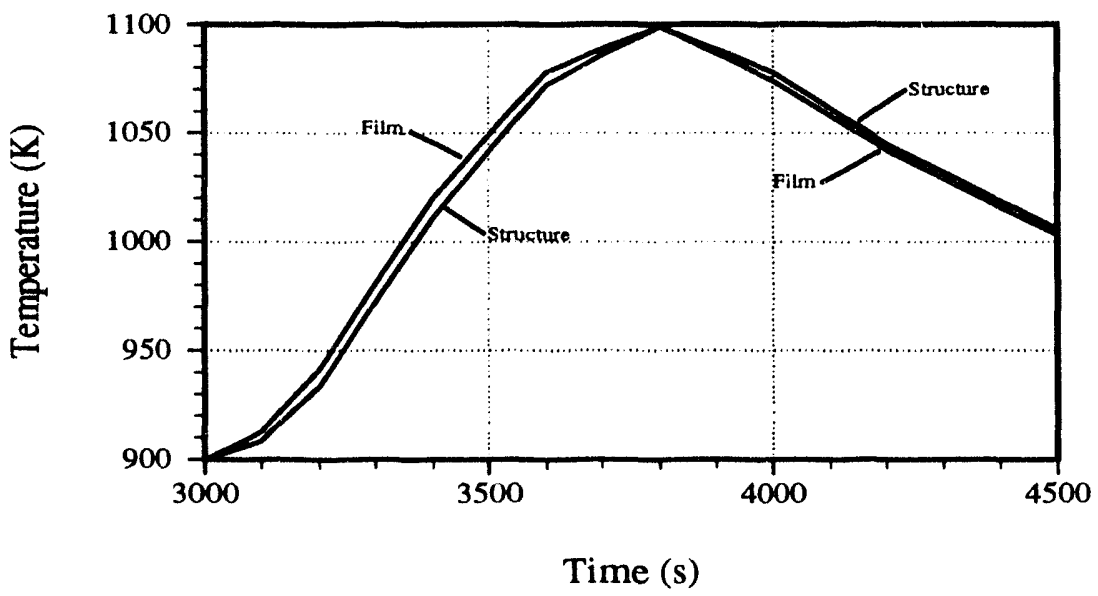

Figure 3. Transient behavior of film and structure temperatures 
maximum then decrease again. The mass reaches a maximum because temperature gets high enough that some revaporization begins to occur. The loss of deposited radionuclides plus the decrease of decay heat with time causes the temperature to peak and then diminish. This relatively simple problem illustrates the phenomena that result from decay heating on structural surfaces.

The heat-up of structures model will be essential for analyzing some accident sequences, such as the steam generator tube rupture sequence. Decay heating is especially important in this sequence because large amounts of radionuclides are likely to be deposited in a small steam generator tube.

\section{References}

1. T. J. Heames, D. A. Williams, N. E. Bixler, A. J. Grimley, C. J. Wheatley, N. A. Johns, and N. M. Chown, VICTORIA: A Mechanistic Model of Radionuclide Behavior in the Reactor Coolant System Under Severe Accident Conditions, SAND90-0756, NUREG/CR-5545, Sandia National Laboratories, October 1990.

2. American National Standard for Decay Heat Power in Light Water Reactors, ANSI/ANS-5.1-1979, August 29, 1979.

3. D. E. Bennett, SANDIA-ORIGEN User's Manual, SAND79-0299, NUREG/CR0987, Sandia National Laboratories, Albuquerque, NM, October 1979.

4. R. M. Ostmeyer, An Approach to Treating Radionuclide Decay Heating for Use in the MELCOR Code System, SAND84-1404, NUREG/CR-4169, Sandia National Laboratories, May 1984.

5. R. B. Bird, W. E. Stewart, and E. N. Lightfoot, Transport Phenomena, John Wiley and Sons, New York, NY, 1960.

6. J. K. Hohorst, editor, SCDAP/RELAP5/MOD2 Code Manual, Volume 4: MATPRO--A Library of Materials Properties for Light-Water-Reactor Accident Analysis, NUREG/CR-5273, EGG-2555 Vol. 4, EG\&G Idaho, February 1990.

7. R. C. Schmidt, P. T. Giguere, T. J. Heames, and S. S. Dosanjh, MELPROG PWR/MOD1 Models and Correlations, SAND89-3123, NUREG/CR-5569, Sandia National Laboratories, May 1991.

8. B. L. Harris, V. N. Shaw, and G. E. Korth, Creep Rupture Failure of Three Components of the Reactor Primary Coolant System During the TMLB' Accident, EGG-EA-7431, EG\&G Idaho, Inc., 1986. 


\section{APPENDIX A.1 \\ Sample Problem Input File}

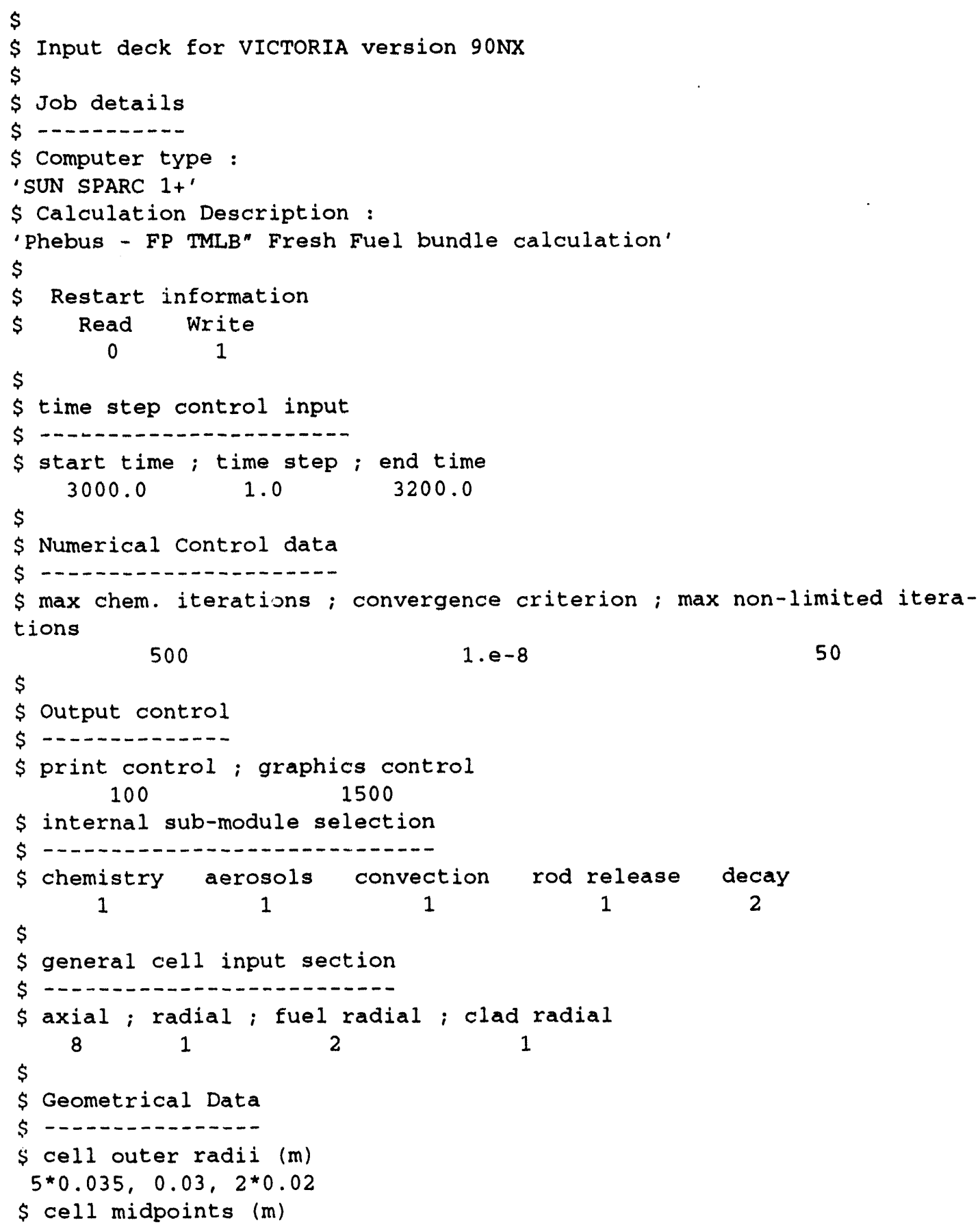


$0.1,0.3,0.5,0.7,0.9,1.05,1.3,1.7$

$\$$ bend flags

$8 \times 0$.

$\$$ settling flags

$8 * 0$.

$\$$ boundary condition flags ( $0=$ zero grad, $1=a$ value)

$8 * 0,0,1,8 * 0$

$\$$ axial cell areas

$5 * 0.002428,0.002828,2 * 0.001257$

$\$$ hydraulic diameters

$5 * 0.0109,0.06,2 * 0.04$

$\$$ floor area in cell

$8 * 0.0$

$\$$ wall area (exclusive of rods) in cell

$5 * 0.178,0.018,2 * 0.503$

$\$$ ceiling area in cell

$5 * 0.0,0.0008,2 * 0.0$

$\$$ structure identification flag (Zirconia walls)

$8 * 0$

$\$$

$\$$ Fuel Data

$\$$-.....-

S pellet diam. ; gap thick. ; clad thick. ; Helium pressure ; frac. theor.dens.
$8.20 \mathrm{e}-3$
$3.6 e-4$
$5.70 e-4$
$1.0 e+5$
0.931

$\$$ number of fuel rods per radial ring

$5 * 21.0,3 * 0.0$

$\$$

\$ continuity input section

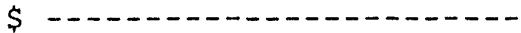

$\$$ initial condition values

1

$\mathrm{H} 2 \mathrm{Og}$

$0.6059,0.3633,0.251,0.242,0.326,0.326,0.467,0.373$

$\$$ boundary condition values

1

$\mathrm{H} 2 \mathrm{Og}$

$8 * 0.0,0.0,0.6135,8 * 0.0$

$\$$

\$nitial fuel grain inventories and diffusion coefficients $\$$

$\$$ Expected order is U, O, Cs, Ba, I, Sr, Zr, Sn, Te, $\mathrm{Kr}, \mathrm{Xe}, \mathrm{Mo}, \mathrm{Ru}, \mathrm{Sb}, \mathrm{Eu}, \mathrm{He}$

$\$$

$\$ U$

\$ Conc. ; dzero; theta

38.127

$\$ 0$

\$ Conc. ; dzero; theta

76.254

$\$$

$\$ C s$

\$ Conc. ; dzero; theta

$3.03 e-0$,

$\$ \mathrm{Ba}$ 


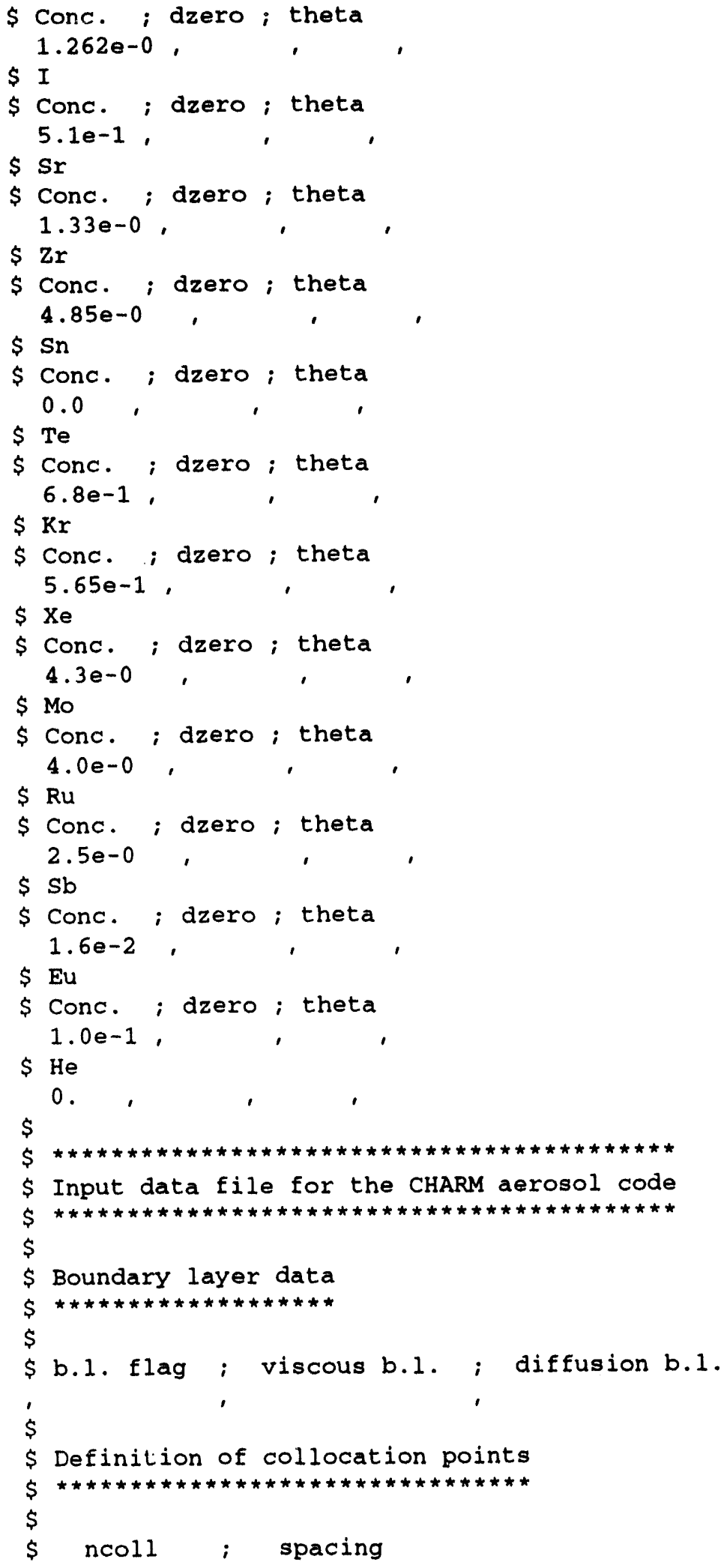




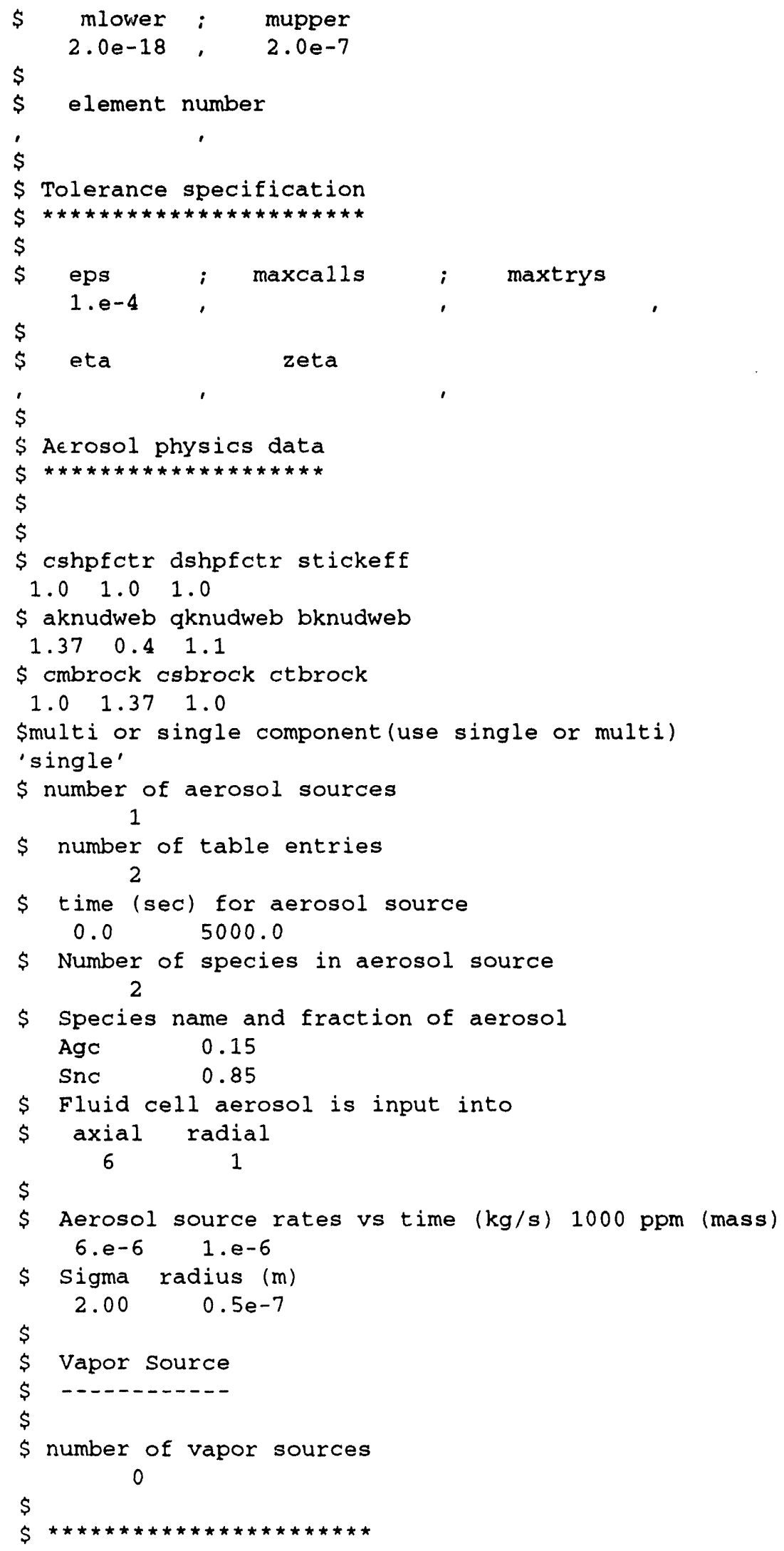




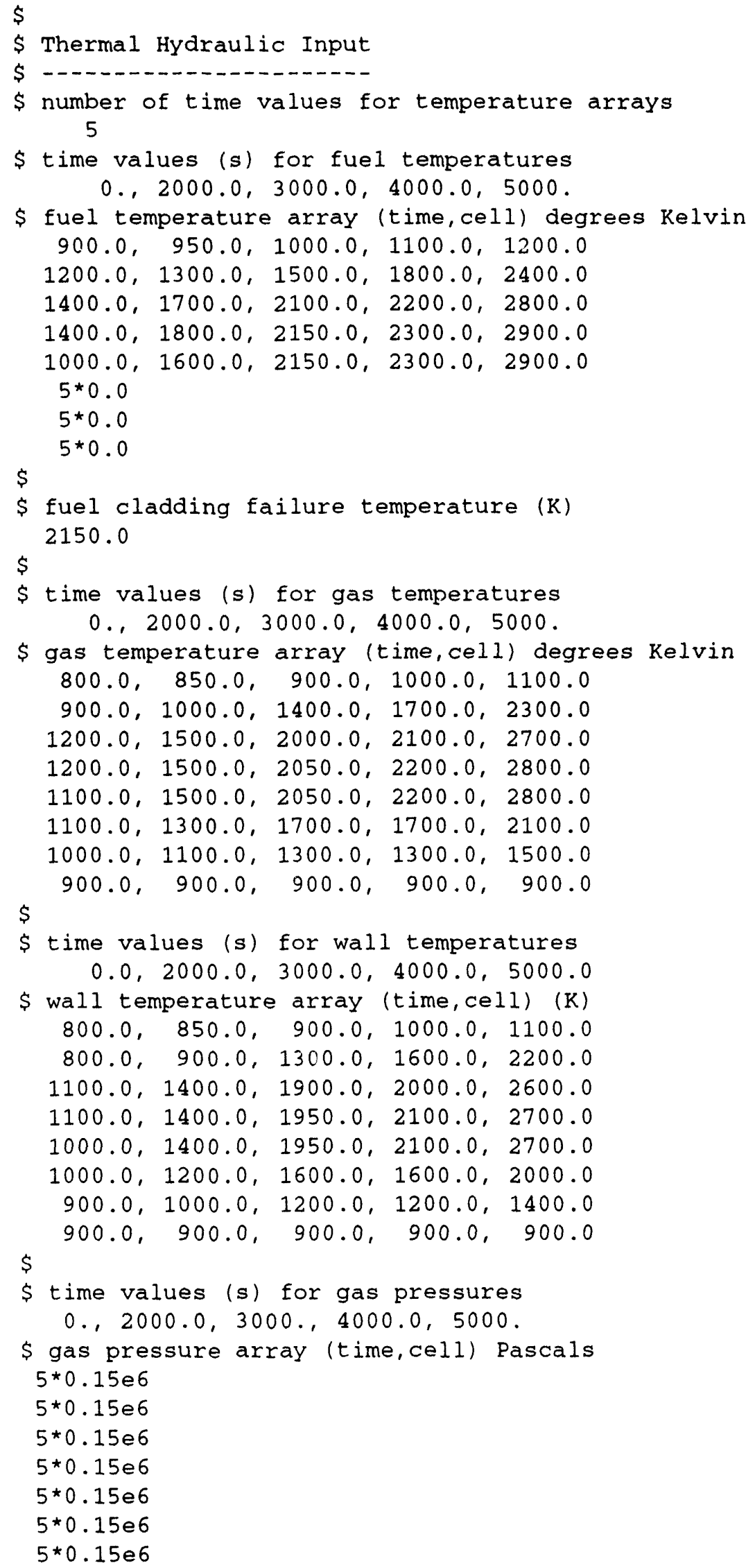




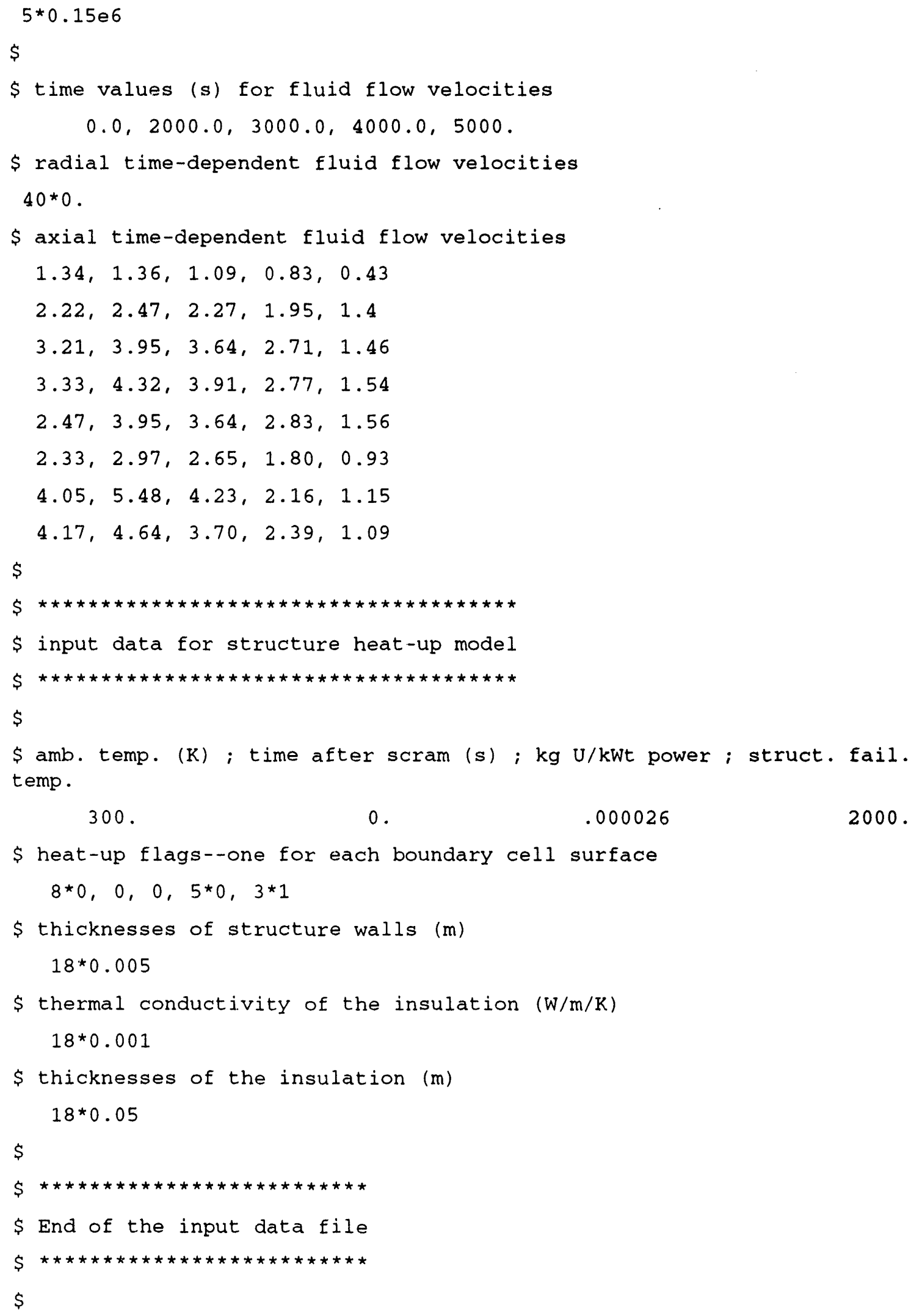




\section{APPENDIX A.2}

\section{Sample Problem Output File}

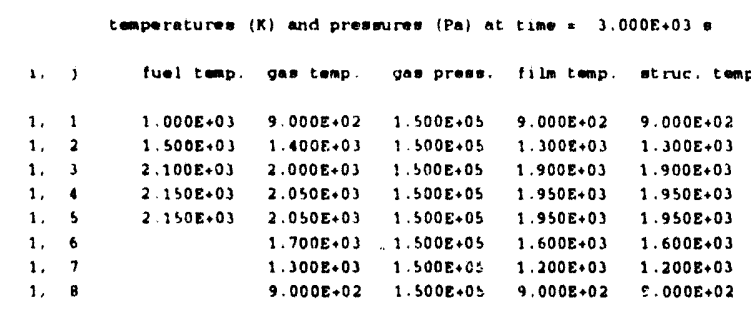

- lemont mavoes (kg) in all colle at t ime $=3.000 E+03$.

\begin{tabular}{|c|c|c|c|c|c|c|c|c|c|c|}
\hline - Lement & grause & poren & gap & elad & $121 \mathrm{~m}$ & bulk gas & aeroeol & structur & total & lost gas \\
\hline$c *$ & C. $158 \mathrm{E}-01$ & & . & . & . & . & & . & 4.158E-01 & \\
\hline 1 & $6.682 \mathrm{E}-02$ & . & . & & . & . & . & . & $6.6828-02$ & . \\
\hline H & . & . & . & . & 1.289E-05 & $7.187 E-04$ & . & $4.3308-05$ & $7.749 \mathrm{E}-04$ & . \\
\hline 80 & $1.789 E-01$ & & . & . & . & . & . & & $1.7898-01$ & . \\
\hline 0 & $1.260 \mathrm{E}+00$ & . & . & . & $1.0318-04$ & $5.749 E-03$ & . & $3.464 \mathrm{E}-04$ & $1.2668+00$ & . \\
\hline sr & $1.203 \mathrm{E}-01$ & . & . & . & . & . & . & . & $1.203 \mathrm{E}-01$ & . \\
\hline $2 r$ & - $.3675-01$ & & $1.020 E-0 S$ & $1,380 E+00$ & $2.245 E-05$ & . & . & . & $1.837 E+00$ & . \\
\hline $\mathbf{s n}$ & & . & $2.9598-07$ & $2.244 E-02$ & $3.651 E-07$ & . & . & . & $2.244 E-02$ & . \\
\hline Te & 8.959E-02 & & . & . & . & . & . & . & $8.959 \mathrm{E}-02$ & . \\
\hline$v$ & $9.369 \varepsilon+00$ & . & . & . & . & . & . & . & $9.36 \div E+00$ & . \\
\hline $\mathrm{kr}$ & 4. $889 \varepsilon-02$ & . & . & . & . & . & . & . & 4.8895-02 & . \\
\hline x. & $3.829 \mathrm{E}-01$ & . & . & . & . & . & . & . & $3.829 \varepsilon-01$ & . \\
\hline Mo & $3.9618-01$ & . & . & . & . & . & . & . & $3.9618-01$ & . \\
\hline nu & 2.0.08 -21 & . & . & . & . & . & . & . & $2.610 \varepsilon-01$ & . \\
\hline sb & $2.01 .2 E-03$ & . & . & . & . & . & . & . & $2.012 \mathrm{E}-03$ & . \\
\hline Eu & 1. $3698-02$ & . & & . & . & . & . & . & $1.5698-02$ & . \\
\hline He & . & $1.227 \mathrm{E}-0 \mathrm{~S}$ & $3.260 \mathrm{E}-0 \mathrm{~S}$ & . & . & . & . & . & 1.487E-03 & . \\
\hline
\end{tabular}

-1ement maeses $(\mathrm{kg})$ in all celle at t $1 \mathrm{mo}=3.000 \mathrm{E}+03$.

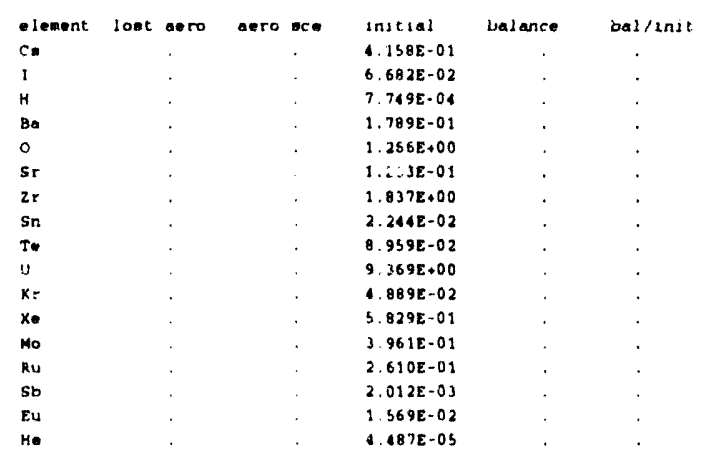

cemperatures $(\mathrm{K})$ and preasurne $(\mathrm{Pa})$ at time $=3.100 \mathrm{E}+03$.

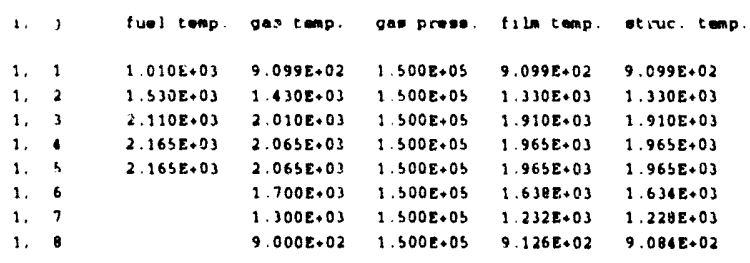

el ment masese (kg) in all colla at time $=3.100 \mathrm{E}+03$. 


\begin{tabular}{|c|c|c|c|c|c|c|c|c|c|c|}
\hline element & graine & pores & gap & elad & film & bulk gas & aeromol & atructure & total & loot gas \\
\hline Cs & $3.651 E-01$ & $3.981 \mathrm{E}-02$ & $1.136 \mathrm{E}-03$ & $8.467 \mathrm{E}-05$ & $1.169 \mathrm{E}-06$ & $8.004 \mathrm{E}-05$ & $2.069 \mathrm{E}-05$ & $2.0778-04$ & $4.065 \mathrm{E}-01$ & $7.745 \mathrm{E}-03$ \\
\hline 1 & $4.992 E-02$ & $1.305 E-02$ & $2.170 \mathrm{E}-04$ & $3.809 \mathrm{E}-0 \mathrm{~S}$ & $5.236 \mathrm{E}-07$ & $3.4758-05$ & $1.379 \mathrm{E}-05$ & $1.3018-04$ & $6.341 E-02$ & $2.479 \mathrm{E}-03$ \\
\hline H & & $7.213 E-07$ & $2.192 \mathrm{E}-06$ & $2.812 \mathrm{E}-06$ & $1.118 \mathrm{E}-05$ & $5.724 E-04$ & $5.014 E-08$ & $3.360 E-05$ & $6.230 \mathrm{E}-04$ & $1.435 E-04$ \\
\hline Be & $1.558 \mathrm{E}-01$ & $2.305 \mathrm{E}-02$ & $7.935 E-06$ & $1.379 E-07$ & $1.876 \mathrm{E}-09$ & $8.703 \mathrm{E}-08$ & $0.366 \mathrm{E}-08$ & $1.2228-06$ & $1.789 \mathrm{E}-01$ & $7.084 \mathrm{E}-06$ \\
\hline 0 & $1.260 E+00$ & $8.241 \mathrm{E}-05$ & $1.986 \mathrm{E}-05$ & $4.133 E-02$ & $7,982 \mathrm{E}-0 \mathrm{~S}$ & $3.520 \mathrm{E}-03$ & $1.116 \mathrm{E}-06$ & $2.221 E-04$ & $1.305 E+00$ & $-3.918 \varepsilon-02$ \\
\hline $\mathrm{sr}$ & $1.194 \mathrm{E}-01$ & $8.864 \mathrm{E}-04$ & $2.911 E-05$ & $2.598 E-07$ & $3.5118-09$ & $1.447 \varepsilon-07$ & $2.552 E-07$ & $2.859 \mathrm{E}-06$ & $1.203 \mathrm{E}-01$ & $1.347 \mathrm{E}-05$ \\
\hline $\mathrm{zr}$ & $4.562 E-01$ & $5.405 \varepsilon-00$ & $1.820 \mathrm{E}-05$ & $1.380 E+00$ & $2.245 \mathrm{E}-05$ & $1.598 \mathrm{E}-17$ & $9.677 E-14$ & $7.971 \mathrm{E}-12$ & $1.837 E+00$ & $1.469 \mathrm{E}-11$ \\
\hline sn & $2.704 \mathrm{E}-08$ & $2.863 E-09$ & $1.508 \mathrm{E}-07$ & $2.244 E-02$ & $3.6518-07$ & $0.5028-07$ & $1.691 \mathrm{E}-06$ & $1.067 \mathrm{E}-05$ & $2.245 \mathrm{E}-02$ & $1.972 \mathrm{E}-05$ \\
\hline Te & $7.105 \mathrm{E}-02$ & $1.853 \mathrm{E}-02$ & $2.557 \varepsilon-07$ & $5.287 \mathrm{E}-08$ & $7.182 \mathrm{E}-10$ & & & & $8.958 E-02$ & $1.991 \mathrm{E}-06$ \\
\hline$v$ & $9.369 E+00$ & $1.273 \mathrm{E}-06$ & $4.001 E-15$ & $7.840 E-17$ & 8.408E-19 & $3.6238-18$ & $3.426 \varepsilon-16$ & $5.785 E-16$ & $9.369 E+00$ & $1.251 \mathrm{E}-15$ \\
\hline $\mathbf{k r}$ & $3.561 \mathrm{E}-02$ & $8.227 E-04$ & $1.379 \mathrm{E}-03$ & $8.846 E-05$ & $1.238 \mathrm{E}-06$ & $1.156 \mathrm{E}-04$ & , & $1.051 \mathrm{E}-05$ & $3.803 \mathrm{E}-02$ & $1.086 \mathrm{E}-02$ \\
\hline xe & $4.249 \mathrm{E}-02$ & $9.828 \mathrm{E}-03$ & $1.645 \mathrm{E}-02$ & $1.054 E-03$ & $1.480 \mathrm{E}-05$ & $1.3765-03$ & & $1.252 \mathrm{E}-04$ & $537 E-01$ & $1.292 \mathrm{E}-01$ \\
\hline Mo & $3.790 \mathrm{E}-01$ & $1.709 \mathrm{E}-02$ & $3.154 \mathrm{E}-13$ & $3.378 \mathrm{E}-15$ & 4.596E-17 & $1.54 B E-15$ & $1.2208-14$ & $4.997 \mathrm{E}-14$ & $3.961 \varepsilon-01$ & $1.544 \varepsilon-13$ \\
\hline$A g$ & 8.611E-22 & $4.598 \mathrm{E}-13$ & $1.577 \mathrm{E}-13$ & $9.429 E-14$ & $9.774 E-14$ & $7.029 \mathrm{E}-08$ & $3.088<-07$ & $1.955 \mathrm{E}-06$ & $2.334 \mathrm{E}-06$ & $3.072 E-06$ \\
\hline Ru & $2.466 \mathrm{E}-01$ & $1,440 \mathrm{E}-02$ & $1.142 \mathrm{E}-12$ & $1.224 \mathrm{E}-14$ & $1.257 \varepsilon-16$ & $1.530 \mathrm{E}-17$ & $5.360 \mathrm{E}-14$ & $1.796 \mathrm{E}-13$ & $2.610 \mathrm{E}-01$ & $3.681 E-13$ \\
\hline$s b$ & $1.903 \mathrm{E}-03$ & $1.090 \mathrm{E}-04$ & $3.453 \mathrm{E}-08$ & $1.894 \mathrm{E}-09$ & $2.588 \mathrm{E}-11$ & $1.150 \mathrm{E}-09$ & $1.186 \mathrm{E}-09$ & $1.938 \mathrm{E}-08$ & $2.012 E-03$ & $1.0638-07$ \\
\hline Eu & $1.545 \mathrm{E}-02$ & $2.348 E-04$ & $4.459 \mathrm{E}-06$ & $4.150 \mathrm{E}-08$ & C. $281 \mathrm{E}-10$ & $1.939 \mathrm{E}-11$ & $1.886 \mathrm{E}-07$ & 5.870 E-07 & $1.569 \mathrm{E}-02$ & $1.207 \mathrm{E}-06$ \\
\hline $\mathrm{He}$ & $7.164 \mathrm{E}-06$ & $4.433 \mathrm{E}-06$ & $1.166 \mathrm{E}-05$ & $3.801 \varepsilon-08$ & $5.7578-10$ & $5.2598-08$ & & $4.6078-09$ & $2.336 \mathrm{E}-05$ & $2.152 E-05$ \\
\hline
\end{tabular}

- lement masser $(\mathrm{kg})$ in all cells at $t$ ime $=3.100 \mathrm{E}+03 \mathrm{~s}$

\begin{tabular}{|c|c|c|c|c|c|}
\hline elenent & lost aern & aeto bce & Initral & balance & bal/init \\
\hline $\mathrm{Ca}$ & 1. $567 E-03$ & & $4.158 \mathrm{E}-01$ & $2.877 \mathrm{E}-08$ & 0.0000000 \\
\hline 1 & $9.341 E-04$ & . & $6.682 E-02$ & $2.212 E-08$ & 0.000000 \\
\hline$H$ & $4.646 \varepsilon-06$ & . & $7.749 \mathrm{E}-04$ & $-3.693 \varepsilon-06$ & 0.004766 \\
\hline$B$ & $4.995 E-06$ & & $1.789 \mathrm{E}-01$ & $6.035 E-09$ & 0.000000 \\
\hline 0 & $9.334 \mathrm{E}-05$ & . & $1.266 \mathrm{E}+00$ & $-2.442 E-0 b$ & 0.000019 \\
\hline sr & $1.5858-05$ & . & $1.203 \varepsilon-01$ & $5.0898-06$ & 0.000042 \\
\hline $2 r$ & $1.079 \mathrm{E}-10$ & . & $1.837 E+00$ & B. $217 \mathrm{E}-11$ & 0.000000 \\
\hline sn & $2.188 \mathrm{E}-04$ & $2.508 E-04$ & $2.244 E-02$ & $4.190 E-07$ & 0.000019 \\
\hline To & $7.486 \mathrm{E}-07$ & . & B. 959 E-02 & $1.035 E-10$ & 0.000000 \\
\hline$u$ & $8.474 \mathrm{E}-15$ & . & $9.369 E+00$ & $-3.553 \mathrm{E}-15$ & 0.000000 \\
\hline $\mathrm{Kr}$ & . & . & 4. $889 \mathrm{E}-02$ & $-4.649 \varepsilon-16$ & 0.000000 \\
\hline xe & . & . & $5.829 \mathrm{E}-01$ & $-1.332 \mathrm{E}-15$ & 0.000000 \\
\hline Mo & $6.148 \mathrm{E}-13$ & & $3.961 \mathrm{E}-01$ & $4.824 \mathrm{E}-13$ & 0.000000 \\
\hline Ag & $3.907 \varepsilon-05$ & $4.426 \mathrm{E}-05$ & & $2.215 E-07$ & \\
\hline Ru & $2.610 \mathrm{E}-12$ & & $2.610 \mathrm{E}-01$ & $1.969 \mathrm{E}-12$ & 0.000000 \\
\hline Sb & $7.859 \mathrm{E}-08$ & . & $2.012 E-03$ & $3.025 \mathrm{E}-10$ & 0.000000 \\
\hline Eu & 8. $564 E-06$ & & $1.569 \mathrm{E}-02$ & $6.459 \mathrm{E}-06$ & 0.000412 \\
\hline He & & & $4.487 E-0 S$ & $-4.005 E-18$ & 0.000000 \\
\hline
\end{tabular}

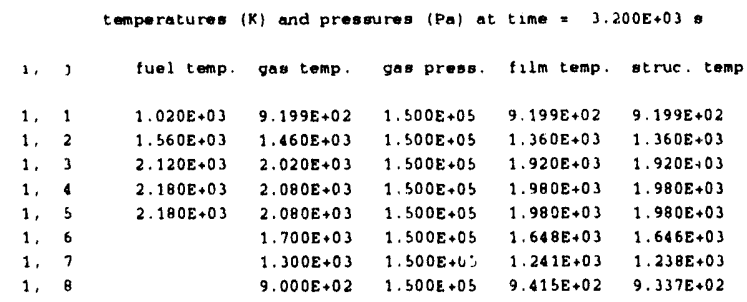

element masses $(\mathrm{kg})$ in all colls at time $=3.200 \mathrm{E}+03 \mathrm{~s}$

\begin{tabular}{|c|c|c|c|c|c|c|c|c|c|c|}
\hline $\begin{array}{l}\text { el ement } \\
\mathrm{Cs}\end{array}$ & $\begin{array}{l}\text { grains } \\
3.498 \mathrm{E}-01\end{array}$ & $\begin{array}{l}\text { pores } \\
4.757 \varepsilon-02\end{array}$ & $\begin{array}{l}\text { gap } \\
1.187 \mathrm{E}-03\end{array}$ & $\begin{array}{l}\text { clad } \\
7.365 \text { E-05 }\end{array}$ & $\begin{array}{l}\mathrm{f} 11 \mathrm{~m} \\
1.037 \mathrm{E}-06\end{array}$ & $\begin{array}{l}\text { bulk gas } \\
0.027 \mathrm{E}-05\end{array}$ & $\begin{array}{l}\text { aerosol } \\
1.7858-05\end{array}$ & $\begin{array}{l}\text { structure } \\
3.6555-04\end{array}$ & $\begin{array}{l}\text { total } \\
3.991 \mathrm{E}-01\end{array}$ & $\begin{array}{l}\text { loot gas } \\
1.374 \mathrm{E}-02\end{array}$ \\
\hline I & $3.800 \mathrm{E}-02$ & $2.149 E-02$ & $2.439 \varepsilon-04$ & $3.164 E-0 S$ & $4.453 E-07$ & $3.004 E-05$ & $1.190 \mathrm{E}-0 \mathrm{~S}$ & $2.680 \mathrm{E}-04$ & $6.015 E-02$ & $4.812 \mathrm{E}-03$ \\
\hline H & & $8.4448-07$ & $522 E-06$ & $2.819 \mathrm{E}-06$ & $1.116 \mathrm{E}-05$ & $5.747 E-04$ & $4.356 \mathrm{E}-08$ & $3.015 E-05$ & $6.263 \mathrm{E}-04$ & 1.333 E-04 \\
\hline Ba & $1.436 \mathrm{E}-01$ & $3.528 \mathrm{E}-02$ & $.347 E-05$ & $1.187 \mathrm{E}-07$ & $1.646 \mathrm{E}-09$ & $7.727 \mathrm{E}-08$ & $7.479 \mathrm{E}-08$ & $2.293 E-06$ & $1.789 \mathrm{E}-01$ & $1.336 \mathrm{E}-$ \\
\hline 0 & $260 E+00$ & $1.698 \mathrm{E}-04$ & $573 E-05$ & $7.775 E-02$ & $7.984 E-05$ & $3.548 E-03$ & $1.009 \mathrm{E}-06$ & $2.288 \mathrm{E}-04$ & $1.342 E+00$ & $-7.581 \mathrm{E}-\mathrm{C}$ \\
\hline $\mathrm{sr}$ & $191 E-01$ & $1.134 E+03$ & $211 E-05$ & $2.518 E-07$ & $3.467 \mathrm{E}-09$ & $1.4408-07$ & $2.5638-07$ & $5.351 \mathrm{E}-06$ & 1. $202 E-01$ & $2.523 \mathrm{E}-\mathrm{C}$ \\
\hline $\mathrm{zr}$ & $.556 \mathrm{E}-01$ & E- 03 & $0 \varepsilon-05$ & $.3808+00$ & $2.245 \mathrm{E}-05$ & $2.932 E-17$ & & & $1.837 E+00$ & \\
\hline sn & $.600 E-08$ & $E-09$ & $2 E-07$ & $2.244 E-02$ & $3.6518-07$ & 4.641E-07 & & E-05 & $2.246 E-02$ & $3.982 \mathrm{E}-$ \\
\hline Te & 5.97 & $5 E-02$ & $6.768 \mathrm{E}-07$ & $9.336 \mathrm{E}-08$ & $1.296 \mathrm{E}-09$ & $8.7678-08$ & $3.479 \mathrm{E}-08$ & $4.057 E-07$ & $8.958 E-02$ & $6.846 \varepsilon-$ \\
\hline u & $9.369 E+00$ & $2.544 \mathrm{E}-06$ & $1.466 \mathrm{E}-14$ & $1.568 \mathrm{E}-16$ & $1.723 \mathrm{E}-18$ & $9.746 E-18$ & $7.307 \mathrm{E}-16$ & $2,261 E-13$ & $9.369 E+00$ & $4.615 \mathrm{E}-$ \\
\hline $\mathrm{Kr}$ & $E-02$ & $7.501 \mathrm{E}-04$ & $2 E-03$ & 4.73 & $6.913 \mathrm{E}-07$ & $6.4698-05$ & . & -06 & $68 E-02$ & $21 \varepsilon-C$ \\
\hline xe & & $E-03$ & $E-02$ & & E- 06 & $7.713 \mathrm{E}-04$ & . & 7.015 E-05 & $3.781 \mathrm{E}-01$ & $2.049 \mathrm{E}-$ \\
\hline Mo & $.782 \mathrm{E}-01$ & $1.783 E-02$ & $.033 E-13$ & $3.564 E-15$ & $4.9468-17$ & $1.679 \mathrm{E}-15$ & $1.352 E-14$ & $9.836 \mathrm{E}-14$ & $3.961 \varepsilon-01$ & $2.980 \mathrm{E}-$ \\
\hline Ag & $3.780 E-21$ & $9.652 \mathrm{E}-13$ & $2.191 \mathrm{E}-13$ & $9.994 E-14$ & $1.034 E-13$ & $7.027 E-08$ & $3.116 \mathrm{E}-07$ & $3.752 E-06$ & $4.134 E-06$ & $6.074 E-$ \\
\hline Ru & $2.457 \varepsilon-01$ & $1.523 \mathrm{E}-02$ & $2.210 \mathrm{E}-12$ & $1.286 \mathrm{E}-14$ & 1. $338 E-16$ & $2.185 E-17$ & $6.165 E-14$ & $3.591 \mathrm{E}-13$ & $2.610 \mathrm{E}-01$ & $7.081 \mathrm{E}-$ \\
\hline Sb & & & $625 E-08$ & & $2.505 \mathrm{E}-11$ & & & & $2.012 \mathrm{E}-03$ & \\
\hline DU & $1.541 \mathrm{E}-02$ & $.628 \mathrm{E}-04$ & $.050 \mathrm{E}-06$ & $3.958 \mathrm{E}-08$ & $4.1348-10$ & $2.485 \mathrm{E}-11$ & 1.902 E-07 & $1.170 \mathrm{E}-06$ & $1.569 \mathrm{E}-02$ & $2.309 E$ \\
\hline He & $7.446 E-06$ & $3.490 \varepsilon-06$ & $9.143 E-06$ & $2.970 E-0 B$ & $4.685 E-10$ & $4.284 \mathrm{E}$ & & 3.754 E-09 & $2.016 E-05$ & $2.472 E-$ \\
\hline
\end{tabular}

element masses $(\mathrm{kg})$ in all cells at $t$ ime $=3.200 E+03 \mathrm{~s}$

\begin{tabular}{|c|c|c|c|c|c|}
\hline element & lost aero & aero sce & instial & balance & bal/1nit \\
\hline Cs & $2.942 E-03$ & & $4.158 E-01$ & $5.217 E-08$ & 0.000000 \\
\hline 1 & $1.861 \mathrm{E}-03$ & & $6.682 E-02$ & $4.124 \mathrm{E}-08$ & 0.000001 \\
\hline H & $7.898 \mathrm{E}-06$ & & $7.749 \mathrm{E}-04$ & $-7.346 E-06$ & 0.009481 \\
\hline Ba & $9.719 E-O E$ & . & $1.789 \mathrm{E}-01$ & $5.826 \mathrm{E}-09$ & 0.000000 \\
\hline$\circ$ & $1.6538-04$ & & $1.266 \mathrm{E}+00$ & $-4.999 E-0 S$ & 0.000039 \\
\hline sr & $3.029 \mathrm{E}-05$ & . & $1.203 E-01$ & $9.361 E-06$ & 0.000078 \\
\hline $2 r$ & 1.131E-10 & . & $1.837 E+00$ & $8.619 \mathrm{E}-11$ & 0.000000 \\
\hline
\end{tabular}




\begin{tabular}{|c|c|c|c|c|c|}
\hline sn & C. $317 E-04$ & 1. $9318=06$ & $2.2448-02$ & $6.078 E-07$ & 0.000031 \\
\hline T० & $2.6648-06$ & . & $8.939 E-02$ & $3.487 E-10$ & 0.000000 \\
\hline u & $3,3368-14$ & - & $9.369 z+00$ & $1.954 z-14$ & 0.000000 \\
\hline $\mathrm{kr}$ & . & . & C.889E-02 & $-5.0658-16$ & 0.0000000 \\
\hline$x=$ & . & . & 3. $829 \mathrm{E}-01$ & $-3.9978-15$ & 0.000000 \\
\hline Mo & $1.285 \mathrm{E}-12$ & . & $3.961 x-01$ & $1.0168-12$ & 0.000000 \\
\hline Ag & $7.710 E-05$ & $8.702 \varepsilon-05$ & . & $3.7448-07$ & \\
\hline Ru & $5.564 E-12$ & & $2.6108-01$ & $4.2548-12$ & 0.000000 \\
\hline sb & $1.493 E-07$ & & $2.0122-03$ & $5.439 E-10$ & 0.000000 \\
\hline EL & $1.817 E-05$ & & $1.569 E-02$ & 1.398E-0S & 0.000884 \\
\hline He & & t & 4.4878-05 & $-4.039 E-18$ & 0.000000 \\
\hline
\end{tabular}

temperatures ( $K$ ) and preseures (Pa) at $t$ ime $=3.400 \mathrm{E}+03$

\begin{tabular}{|c|c|c|c|c|c|}
\hline i, , & fuel temp. & gas temp. & gas proses. & tiin temp. & true te \\
\hline 1 & $1.040 E+03$ & $9.399 E+02$ & $1.500 E+05$ & $9.399 \mathrm{E}+02$ & $9.399 \mathrm{E}+02$ \\
\hline 2 & $1.620 \mathrm{E}+03$ & $1.320 \mathrm{E}+03$ & $1.500 \mathrm{z}+05$ & $1.420 \varepsilon+03$ & $1.4208+03$ \\
\hline 3 & $2.1408+03$ & $2.040 E+03$ & $1.500 z+05$ & $1.960 E+03$ & $1.960 \mathrm{E}+03$ \\
\hline 4 & $2.210 z+03$ & $2.110 z+03$ & $1.500 z+05$ & $2.010 \mathrm{E}+03$ & $2.010 E+03$ \\
\hline 3 & $2.2108+03$ & $2.110 \mathrm{E}+03$ & $1.500 z+05$ & $2.0108+03$ & $2.0108+03$ \\
\hline 6 & & $1.700 \mathrm{E}+03$ & $1.500 E+05$ & $1.665 \varepsilon+03$ & $1.6648+03$ \\
\hline 7 & & $1.300 E+03$ & $1.500 \mathrm{E}+0 \mathrm{~s}$ & $1.2578+03$ & $1.253 E+03$ \\
\hline$\theta$ & & $9.000 \varepsilon+02$ & $1.500 \varepsilon+05$ & $1.020 \mathrm{E}+03$ & $1.011 E+03$ \\
\hline
\end{tabular}

-lement massas $(\mathrm{kg})$ in all colle at time $=3,400 \mathrm{E}+03$.

\begin{tabular}{|c|c|c|c|c|c|c|c|c|c|c|}
\hline 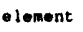 & rain. & ports & gap & clad & tilm & bulk ga: & & structure & total & lost gae \\
\hline & $3.347 E-01$ & $5.322 E-02$ & $1,2558-03$ & $4.634 E-06$ & $8.393 E-00$ & $6.673 E-06$ & $8.502 E-07$ & $4.073 E-04$ & $3.896 \mathrm{E}-01$ & $2.167 z-02$ \\
\hline & $2.830 \varepsilon-02$ & $2.778 E \div 02$ & $2.180 \mathrm{E}-04$ & $1.606 E-06$ & $2.914 E-08$ & $1.9068-06$ & $7.227 E-07$ & $3.799 \varepsilon-04$ & $5.668 \varepsilon-02$ & $7.2578-03$ \\
\hline & & $1.000 E-06$ & $2.936 E-06$ & $2.833 E-06$ & $1.113 \mathrm{E}-05$ & $5.803 E-04$ & $1.456 \bar{E}-09$ & $3.4485-05$ & $6.326 \mathrm{E}-04$ & $1.1608-04$ \\
\hline & $1.3408-01$ & 1.485E-02 & $2.219 \varepsilon-03$ & $1.017 \varepsilon-08$ & $1.590 \mathrm{E}+10$ & $7.715 \mathrm{E}-09$ & $7.778 E-09$ & $3.829 \mathrm{E}-06$ & $1.789 \varepsilon-01$ & $2.217 \varepsilon-05$ \\
\hline & $1.260 \mathrm{E}+00$ & $2.902 E-04$ & $3.4618-05$ & $1.4918-01$ & $7.927 E-05$ & $3.361 E-03$ & $3.195 \mathrm{E}-07$ & $2.2638-01$ & $1.413 E+00$ & $-1.475 E-01$ \\
\hline & $1.187 E-01$ & $1.403 E-03$ & 8. $2968-05$ & $6.820 \varepsilon-08$ & $9.7318-10$ & 1. 200E-08 & $6.803 E-08$ & $9.324 E-06$ & $1.202 \mathrm{E}+01$ & $1.2668-05$ \\
\hline & $1.346 x-01$ & $2.112 \mathrm{E}-0 \mathrm{~J}$ & $1.820 \mathrm{E}-03$ & $1.380 \mathrm{E}+00$ & $2.2458-0 b$ & 3.39 & $7 E-12$ & $9.955 E-12$ & $1.8378 \times 00$ & $1.666 \mathrm{E}-11$ \\
\hline & $4.454 E-00$ & $3,585 E-09$ & $1.2988-07$ & $2.244 \varepsilon-02$ & $3.6518-07$ & C.4418-07 & $1.739 \varepsilon-06$ & $3.963 \mathrm{E}-05$ & $2.248 E-02$ & 7. $888 \mathrm{EE-05}$ \\
\hline & $3.082 E-02$ & $3.874 \varepsilon-02$ & $1.7398-06$ & $3.5938-09$ & $6.4938-11$ & 13E-09 & $1.576 E-09$ & $9.614 z+07$ & $8.956 E-02$ & $1.7418-05$ \\
\hline & $9.369 \mathrm{E}+00$ & $3.096 E-06$ & $4.785 E-14$ & $8.128 E-21$ & $1.758 \mathrm{E}-21$ & 6. $395 E-20$ & $1.675 E-15$ & 8.945 & $9 E+00$ & $1.327 E-14$ \\
\hline & $2.4518-02$ & $7.221 \mathrm{E}-04$ & $1.5918-03$ & $8.5298-06$ & $1.3398-07$ & $1.342 E-05$ & & 1.181E-06 & $2.6858-02$ & $2.206 \mathrm{E}-02$ \\
\hline & $2.926 \mathrm{E}-01$ & $6.630 \mathrm{E}-03$ & 1. $9008-02$ & $1.015 E-04$ & $1.836 E-06$ & $1.596 \varepsilon-04$ & & $1.4058-05$ & $3.205 E-01$ & $2.625 \mathrm{E}-01$ \\
\hline & $3.767 E-01$ & $1.9368-02$ & $1.094 E-12$ & $1.9598-16$ & $2.7058-18$ & $1.1658-16$ & 8. $2545-16$ & $\therefore .793 E-13$ & $3.961 E-01$ & $5.2068-13$ \\
\hline & $1.689 \mathrm{E}-20$ & $1.697 E-12$ & $2.732 E-13$ & 1. $303 \mathrm{E}-13$ & $1.171 \mathrm{E}-13$ & $7.073 E-00$ & $3.152 \mathrm{E}-07$ & & $7.8078-06$ & $1.1808-05$ \\
\hline & $2.4508-01$ & $1.599 \mathrm{E}-02$ & & & & & & & $2,6108-01$ & $1.215 E-12$ \\
\hline & $1.893 \mathrm{E}-03$ & $1.189 E-04$ & $8.469 E-00$ & $6.4348-11$ & $1.163 \mathrm{E}-12$ & S. $156 z-11$ & $3.027 \mathrm{E}-11$ & $5.892 \varepsilon-08$ & $2.012 E-03$ & $3.1708-07$ \\
\hline & $1.5378-02$ & $2.917 E-04$ & $1.635 E-05$ & $5.925 E-13$ & $1.227 z-14$ & $3.980 \mathrm{E}-13$ & $2.229 E-07$ & 2. $249 \mathrm{E}-06$ & $1.560 \mathrm{E}-02$ & $3.728 \mathrm{E}-06$ \\
\hline & & $.319 E-06$ & $.038 \varepsilon-06$ & $2.128 \mathrm{E}-08$ & $3.612 E-10$ & $3.366 E-08$ & & $2.9498-09$ & $1.533 E-05$ & $1.955 E-0$ \\
\hline
\end{tabular}

element masser $(\mathrm{kg})$ in all celin at time $=3.000 \mathrm{E}+03$.

\begin{tabular}{|c|c|c|c|c|c|}
\hline $\begin{array}{l}\text { - lement } \\
\text { C. }\end{array}$ & $\begin{array}{l}\text { lout aero } \\
4.540 E-03\end{array}$ & aero ace & $\begin{array}{l}\text { initial } \\
\text { t.158E-01 }\end{array}$ & $\begin{array}{l}\text { bolance } \\
4.005 E-07\end{array}$ & $\begin{array}{l}0.1 / \text { inst } \\
0.000001\end{array}$ \\
\hline$I$ & $2.6818-03$ & . & $6.682 E-02$ & $1.9978-07$ & 0.000003 \\
\hline H & $1.221 \mathrm{E}-05$ & . & $7.7498-04$ & $-1.399 \mathrm{E}-0 \mathrm{~S}$ & 0.018056 \\
\hline Ba & $1.682 E-05$ & . & $1.789 \mathrm{E}-01$ & $-9.516 E-09$ & 0.000000 \\
\hline o & $2.720 \mathrm{E}-0 \mathrm{C}$ & . & $1.266 \mathrm{E}+00$ & $-9.0158-05$ & 0.000078 \\
\hline$s_{r}$ & $5.3208-05$ & . & $1.203 \varepsilon-01$ & $1.596 \mathrm{E}-05$ & 0.000133 \\
\hline $2 r$ & $1.460 \mathrm{E}-10$ & . & $1.837 E+00$ & $1.1928-10$ & 0.000000 \\
\hline sn & $8.3288-04$ & $9.522 E-04$ & $2.244 E-02$ & $1.172 E-06$ & 0.000052 \\
\hline Te & $7.070 E-06$ & • & $8.959 E-02$ & $1.298 \mathrm{E}-09$ & 0.000000 \\
\hline u & $1.558 E-13$ & . & $9.369 E+00$ & $1.243 E-13$ & 0.000000 \\
\hline $\mathrm{kr}$ & . & . & $4.889 E-02$ & $2.1018-07$ & 0.000004 \\
\hline$x_{0}$ & . & . & 5.829E-01 & $2.503 E-06$ & 0.000004 \\
\hline mo & $2.377 E-12$ & & $3.961 E-01$ & $1.868 \mathrm{E}-12$ & 0.000000 \\
\hline Ag & $1.491 \mathrm{E}-04$ & $1.680 E-04$ & & $6.470 E-07$ & \\
\hline Ru & $1.271 \mathrm{E}-11$ & 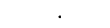 & $2.610 \varepsilon-01$ & $1.045 E-11$ & 0.000000 \\
\hline sb & $2.535 E-07$ & . & $2.012 \mathrm{E}-03$ & $8.990 E-10$ & 0.000000 \\
\hline Eu & $3.7385-05$ & . & $1.569 \mathrm{E}-02$ & $3.058 \mathrm{E}-05$ & 0.001949 \\
\hline He & & & $4.487 \mathrm{E}-05$ & $1.336 E-10$ & 0.000003 \\
\hline
\end{tabular}

tomperatures $(\mathrm{K})$ and presaures $(\mathrm{Pa})$ at $\mathrm{t}$ ine $=3.600 \mathrm{E}+03$

\begin{tabular}{|c|c|c|c|c|c|}
\hline 1. $j$ & f wel temp. & gat temp. & gas preses. & $t i \ln$ temp. & ot ruc, te \\
\hline & $\therefore .060 \mathrm{E}+03$ & $9.599 E+02$ & 1.5005005 & $9.399 E+02$ & $9.599 \varepsilon+02$ \\
\hline 1. & $1.6808+03$ & $1.580 E+03$ & $1.500 E+05$ & $1.480 E+03$ & $1.480 \mathrm{E}+03$ \\
\hline 1. & $2.160 \mathrm{E} * 03$ & $2.060 \varepsilon+03$ & $1.500 \mathrm{E}+05$ & $1.960 \mathrm{E}+03$ & $1.960 \varepsilon+03$ \\
\hline 1. & $2.240 \varepsilon \cdot 03$ & $2.140 \mathrm{E}+03$ & $1.300 E+05$ & $2.060 E+03$ & $2.040 \mathrm{E}+03$ \\
\hline 1. & $2.2408+03$ & $2,140 E+03$ & $1.500 E+05$ & $2.040 E+03$ & $2.0408+03$ \\
\hline 1. & & $1.700 E+03$ & $1,500 E=05$ & $1.676 \varepsilon+03$ & $1.675 \varepsilon+03$ \\
\hline 1. & & $1.300 \mathrm{E}+03$ & $1.500 \mathrm{E}+05$ & $1.269 \mathrm{E}+03$ & $1.260 \mathrm{E}+03$ \\
\hline 1. & & $9.000 \mathrm{E}+02$ & $1.500 \mathrm{E}+05$ & $1.078 \mathrm{E}+03$ & $1.072 \mathrm{E}+03$ \\
\hline
\end{tabular}

clement maseos $(\mathrm{kg})$ in all celle at time $=3.600 \mathrm{E}+03=$

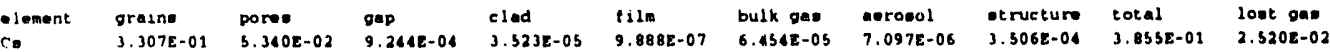
$\begin{array}{lllllllllll}0 & 3.307 E-01 & 5.360 E-02 & 9.264 E-04 & 3.523 E-05 & 9.888 E-07 & 6.454 E-05 & 7.097 \varepsilon-08 & 3.3068-04 & 3.855 E-01 & 2.5208-02 \\ 1 & 2.671 E-02 & 2.825 E-02 & 7.954 E-05 & 9.992 E-06 & 2.011 E-07 & 1.578 E-05 & 6.727 E-06 & 3.200 E-04 & 3.538 E-02 & 8.156 E-03\end{array}$ 


\begin{tabular}{|c|c|c|c|c|c|c|c|c|c|c|}
\hline H & & $1.139 \mathrm{E}-06$ & $3.5248-06$ & $4.3218-06$ & $1.1108-05$ & $5.8738-04$ & $1.9258-08$ & 3.5578-05 & $6.429 \mathrm{E}-04$ & $9.7438-05$ \\
\hline Ba & $1.329 \mathrm{E}-01$ & C.592E-02 & $1.800 \mathrm{E}-05$ & $1.31 \mathrm{BE}-07$ & $3.707 \varepsilon-09$ & $1.619 \mathrm{E}-07$ & $9.840 \mathrm{E}-08$ & $5.020 \mathrm{E}-06$ & $1.789 \mathrm{E}-01$ & $2.920 \mathrm{E}-03$ \\
\hline 0 & $1.260 \mathrm{E}+00$ & $3.543 E-06$ & $4.593 \mathrm{E}-05$ & $1.878 \mathrm{E}-01$ & $8.679 \mathrm{E}-0 \mathrm{~s}$ & C.521E-03 & 8.345E-07 & $2.932 \mathrm{E}-04$ & $1.453 \mathrm{E}+00$ & $-1.074 \varepsilon-01$ \\
\hline sr & $1.186 \mathrm{E}-01$ & $1.538 \mathrm{E}-03$ & $8.423 E-05$ & $1.856 \mathrm{E}-07$ & 4.293E-09 & $1.753 E-07$ & $2.030 z-07$ & $1.1728-05$ & $1.202 \mathrm{E}-01$ & $3.316 E-05$ \\
\hline $2 r$ & $4.5368-01$ & $3.0738-03$ & $1.820 \mathrm{E}-0 \mathrm{~S}$ & $1.359 E+00$ & $2.245 E-05$ & $7.063 \varepsilon-16$ & $8.973 E-13$ & $1.6398-11$ & $1.815 \varepsilon+00$ & 1.B18E-11 \\
\hline $\mathrm{sn}$ & 8. $373 \mathrm{E}-08$ & $1.060 \mathrm{E}-08$ & $7.260 \mathrm{E}-08$ & $1.496 \mathrm{E}-02$ & $3.651 \mathrm{E}-07$ & $6.277 \mathrm{E}-07$ & $1.830 \varepsilon-06$ & $3.596 \mathrm{E}-0 \mathrm{~S}$ & $1.502 \mathrm{E}-02$ & $1.1278-04$ \\
\hline To & $4.984 \mathrm{E}-02$ & $3.972 E-02$ & $3.082 \mathrm{E}-07$ & C.524E-OB & $1.269 \mathrm{E}-09$ & $7.076 E-08$ & $2.0348-08$ & $1.099 \mathrm{E}-06$ & $8.956 \mathrm{E}-02$ & $2.123 \mathrm{E}-0 \mathrm{~S}$ \\
\hline$u$ & $9.369 \mathrm{E}+00$ & $7.680 \mathrm{E}-06$ & $6.7268-14$ & $1.386 \mathrm{E}-16$ & $2.666 \mathrm{E}-18$ & $2.734 E-17$ & $2.010 \mathrm{E}-1 \mathrm{~s}$ & $1.4738-14$ & $9.369 \mathrm{E}+00$ & $1.545 \mathrm{E}-14$ \\
\hline $\mathrm{kr}$ & $2.199 \mathrm{E}-02$ & 1. $.537 \mathrm{E}-04$ & $7.994 E-04$ & $1.7308-05$ & $4.853 E-07$ & $3.531 \mathrm{E}-05$ & $\cdot$ & $2.8438-06$ & $2.330 \mathrm{E}-02$ & $2.5598-02$ \\
\hline$x_{0}$ & $2.6248-01$ & $5.4328-03$ & $9.556 \mathrm{E}-03$ & $2.067 E-04$ & $5.813 \mathrm{E}-06$ & $4.218 \mathrm{E}-04$ & . & $3.396 \mathrm{E}-05$ & $2,7818-01$ & $3.0498-01$ \\
\hline Mo & $3.753 \mathrm{E}-01$ & $2.072 E-02$ & $1.191 \mathrm{E}-12$ & $1.855 \mathrm{E}-15$ & $4.175 E-17$ & $1.5918-15$ & $1.0598-14$ & $2.0468-13$ & $3.9618-01$ & $3.899 E-13$ \\
\hline$A g$ & $3.418 \mathrm{E}-20$ & $1.700 E-12$ & $1.6578-13$ & $1.221 \mathrm{E}-13$ & $1.190 \mathrm{E}-13$ & 6.9998-08 & $3.299 E-07$ & $1.040 \mathrm{E}-05$ & $1.080 \mathrm{E}-05$ & $1.7108-05$ \\
\hline Ru & $2.444 E-01$ & $1.6578-02$ & $1.714 E-12$ & $3.876 E-15$ & $7.3318-17$ & $6.032 \mathrm{E}-16$ & $5.7078-14$ & $1.000 z-12$ & $2.6108-01$ & $1.279 E-12$ \\
\hline sb & $1.889 \mathrm{E}-03$ & $1.224 E-04$ & $2.586 \mathrm{E}-08$ & $6.982 \mathrm{E}-10$ & $1.959 \mathrm{E}-11$ & 8.204z-10 & $5.553 z-10$ & C.958E; 08 & $2.0118-03$ & $3.764 E-07$ \\
\hline Ex & $1.535 \mathrm{E}-02$ & $3.093 \mathrm{E}-04$ & $1.961 \mathrm{z}-05$ & $1.542 E-08$ & $2.661 \mathrm{E}-10$ & $2.198 E-11$ & $2.3248-07$ & $2.990 \mathrm{E}-06$ & $1.568 \mathrm{E}-02$ & $3.941 E-06$ \\
\hline $\mathrm{H}$ & $3.480 E-06$ & $1.089 \mathrm{E}-06$ & $2.647 \mathrm{E}-06$ & $3.7548-08$ & $1.006 \varepsilon-09$ & $7.665 \mathrm{E}-08$ & & $6.177 \mathrm{E}-09$ & $7.338 \mathrm{E}-06$ & $3.754 E-0 S$ \\
\hline
\end{tabular}

elomont massen $(\mathrm{kg})$ in all colle at time = 3.6008+03.

\begin{tabular}{|c|c|c|c|c|c|}
\hline $\begin{array}{l}\text { element } \\
\text { Cs }\end{array}$ & $\begin{array}{l}108 t \text { aero } \\
5.123 \mathrm{E}-03\end{array}$ & aero ace & $\begin{array}{l}\text { initial } \\
\text { A.158E-01 }\end{array}$ & $\begin{array}{l}\text { balance } \\
4.087 E-07\end{array}$ & $\begin{array}{l}\text { bal/init } \\
0.000001\end{array}$ \\
\hline I & $3.282 E-03$ & . & $6.682 E-02$ & $2.056 \mathrm{E}-07$ & 0.000003 \\
\hline H & $1.368 \mathrm{E}-05$ & . & $7.749 E-04$ & $-2.080 \mathrm{E}-0 \mathrm{~S}$ & 0.026848 \\
\hline Bo & $2.321 \mathrm{E}-05$ & . & $1.789 \mathrm{E}-01$ & $-1.518 E-08$ & 0.000000 \\
\hline 0 & $3.4298-04$ & . & $1.266 \mathrm{E}+00$ & $-1.459 E-04$ & 0.000115 \\
\hline sr & $6.736 \mathrm{E}-05$ & & $1.203 \mathrm{E}-01$ & $1.908 \mathrm{E}-0 \mathrm{~b}$ & 0.000159 \\
\hline $2 r$ & $3.257 \mathrm{E}-10$ & ' $\quad$. & $1.837 E+00$ & $-2.138 \mathrm{E}-02$ & 0.011641 \\
\hline$s n$ & $1.208 \mathrm{E}-03$ & $1.377 \mathrm{E}-03$ & $2.244 E-02$ & $-7.4798-03$ & 0.333257 \\
\hline To & $8.822 \mathrm{E}-06$ & & $8.9598-02$ & $1.653 \mathrm{E}-09$ & 0.000000 \\
\hline$u$ & $3.193 \mathrm{E}-13$ & . & $9.369 E \cdot 00$ & $2.700 \mathrm{E}-13$ & 0.000000 \\
\hline $\mathbf{k r}$ & . & . & 4. $889 \mathrm{E}-02$ & $2.101 E-07$ & 0.000004 \\
\hline$x_{0}$ & . & . & $5.829 z-01$ & $2.303 E-06$ & 0.000004 \\
\hline Ho & $2.833 E-12$ & . & $3.961 \mathrm{E}-01$ & $2.255 E-12$ & 0.000000 \\
\hline$A \sigma$ & $2.160 \varepsilon-04$ & $2.430 E-04$ & . & $8.621 \mathrm{E}-07$ & \\
\hline Ru & $1.960 \mathrm{E}-11$ & . & $2.610 \mathrm{E}-01$ & $1.7298-11$ & 0.000000 \\
\hline Sbo & $3.125 \mathrm{E}-07$ & . & $2.012 \mathrm{E}-03$ & $1.055 E-09$ & 0.000001 \\
\hline EU & $3.889 \mathrm{E}-0 \mathrm{~S}$ & . & $1.569 \mathrm{E}-02$ & $5.143 E-05$ & 0.003277 \\
\hline & & & $4.487 E-05$ & $1.338 \mathrm{E}-10$ & 0.000003 \\
\hline
\end{tabular}

temperatures (K) and presences (Pa) at time = 3.800E+03.

\begin{tabular}{|c|c|c|c|c|c|}
\hline j & fuel temp. & gas tenp. & gas preas. & tiin temp. & \\
\hline 1 & $1.0808+03$ & $9.7998+02$ & $1.500 E+05$ & $9.799 \mathrm{E}+02$ & $9.799 E+02$ \\
\hline 2 & $1.740 E+03$ & $1.6408+03$ & $1.500 E+05$ & $1.540 E+03$ & $1.560 z+03$ \\
\hline 3 & $2.180 E+03$ & $2.080 E+03$ & $1.500 \varepsilon+05$ & $1.980 E+03$ & $1.980 E+03$ \\
\hline 4 & $2.270 E+03$ & $2.170 E+03$ & $1.500 \varepsilon+05$ & $2.070 E+03$ & $2.070 \varepsilon+03$ \\
\hline s & $2.270 E+03$ & $2.170 E+03$ & $1.300 E+05$ & $2.070 \varepsilon+03$ & $2.070 \mathrm{E}+03$ \\
\hline 6 & & $1.700 E+03$ & $1.500 E+05$ & $1.683 E+03$ & $1.682 E+03$ \\
\hline$?$ & & $1.300 E+03$ & $1.500 \varepsilon+05$ & $1.277 \varepsilon+03$ & $1.276 E+03$ \\
\hline 8 & & $9.000 \mathrm{E}+02$ & $1.500 E+05$ & $1.0998+03$ & $1.099 E+03$ \\
\hline
\end{tabular}

element maseos (kg) in afl colls at time $=3.900 \mathrm{E}+03$.

\begin{tabular}{|c|c|c|c|c|c|}
\hline 1 ement & grains & pores & sap & clad & film \\
\hline$c$ & $3.259 E-01$ & $5.162 E-02$ & $8.874 E-04$ & $3.397 \mathrm{E}-05$ & $1.007 E^{-}$ \\
\hline I & $2.636 \mathrm{E}-02$ & $2.682 E-02$ & $9.093 \mathrm{E}-05$ & 8.683E-06 & $2.378 \mathrm{E}-\mathrm{C}$ \\
\hline H & & $1.185 E-06$ & $3.677 \varepsilon-06$ & 4. $3458-06$ & $1.107 \mathrm{E}-$ \\
\hline Ba & $1.3408-01$ & $4.486 \mathrm{E}-02$ & $1.303 E-05$ & $7.4398-08$ & $2.200 E-$ \\
\hline 0 & $1.260 E+00$ & 1. $813 \mathrm{E}-04$ & 1.665E-OS & $1.976 \mathrm{E}-01$ & $8.6238-$ \\
\hline st & $1.183 E-01$ & $1.788 E-03$ & $8.2428-03$ & $1.478 \varepsilon-07$ & $4.2268-$ \\
\hline $2 \mathrm{r}$ & 4.528E-01 & $3.9368-03$ & $1.820 \mathrm{E}-05$ & $1.3598+00$ & $2.245 E-$ \\
\hline sn & $9.098 \mathrm{E}-08$ & $7.017 E-09$ & $6.818 \mathrm{E}-08$ & $1.496 \mathrm{E}-02$ & $3.651 E-$ \\
\hline Te & $5.0898-02$ & $3.866 \mathrm{E}-02$ & $2.3868-07$ & $5.789 E-08$ & $1.714 \mathrm{E}-$ \\
\hline u & $9.369 E+00$ & $1.030 \mathrm{E}-05$ & 8.895E-14 & $2.497 E-16$ & $5.181 \mathrm{E}-$ \\
\hline $\mathbf{k r}$ & $2.033 E-02$ & $3.474 E-04$ & $6.005 E-04$ & $6.3538-96$ & $1.877 \mathrm{E}$ \\
\hline$x_{e}$ & $2.425 E-01$ & $4.1658-03$ & $7.1918-03$ & $7.593 \mathrm{E}-05$ & 2.2498 \\
\hline No & $3.745 E-01$ & $2.1618-02$ & $9.845 E-13$ & $4.448 E-15$ & $9.247 \mathrm{E}$ \\
\hline Ag & $5.371 E-20$ & $1.701 E-12$ & $1.341 \mathrm{E}-13$ & $1.389 \mathrm{E}-13$ & $1.358 \mathrm{E}$ \\
\hline Ru & $2.439 \mathrm{E}-01$ & $1.702 \mathrm{E}-02$ & $5.244 \varepsilon-12$ & $5.5498-15$ & $1.0738-$ \\
\hline sb & $1.886 \mathrm{E}-03$ & $1.256 \varepsilon-04$ & $2.659 \varepsilon-08$ & $7.900 E-10$ & $2.338 \mathrm{E}$ \\
\hline Eu & $1.5338-02$ & $3.279 E-04$ & $2.221 \mathrm{E}-05$ & $1.773 \mathrm{E}-08$ & 3.1398 \\
\hline \multirow[t]{2}{*}{ He } & $1.496 \mathrm{E}-06$ & $4.913 \mathrm{E}-07$ & $1.213 \mathrm{E}-08$ & $1.110 E-08$ & 3.1478 \\
\hline & \multicolumn{3}{|c|}{ element masees } & \multicolumn{2}{|c|}{$t$ LAOE $=3.800 E+03$} \\
\hline element & lost oero & aero sce & initial & balance & bal/init \\
\hline C: & $6.089 \mathrm{E}-03$ & & $4.158 \mathrm{E}-01$ & $4.217 E-07$ & 0.000001 \\
\hline 1 & $3.915 \mathrm{E}-03$ & . & $6.682 \mathrm{E}-02$ & $2.144 E-07$ & 0.000003 \\
\hline H & $1.630 \mathrm{E}-05$ & . & $7.7498-04$ & $-2.735 E-05$ & 0.035294 \\
\hline Ba & $3.171 E-05$ & . & $1.789 \mathrm{E}-01$ & $-7.364 E-08$ & 0.000000 \\
\hline 0 & $1.420 E-04$ & . & $1.266 E+00$ & $-1.914 E-04$ & 0.000151 \\
\hline $\mathbf{s r}$ & 8.745E-05 & & 1. $203 E-01$ & $2.3118-05$ & 0.000192 \\
\hline $2 r$ & $6.247 E-10$ & & $1.837 \mathrm{E}+00$ & $-2.138 \mathrm{E}-02$ & 0.011641 \\
\hline sn & $1.556 \mathrm{E}-03$ & $1.768 E-03$ & $2.244 E-02$ & $-7.478 \mathrm{E}-03$ & 0.333245 \\
\hline To & 1. $208 \mathrm{EE}-05$ & . & 8. $9598-02$ & $2.3078-09$ & 0.000000 \\
\hline$u$ & $5.5618-13$ & . & $9.369 \mathrm{E}+00$ & 4. $.796 E-13$ & 0.000000 \\
\hline $\mathbf{k r}$ & 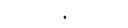 & . & $4.889 \mathrm{E}-02$ & $2.101 \mathrm{E}-07$ & 0.00000 \\
\hline
\end{tabular}




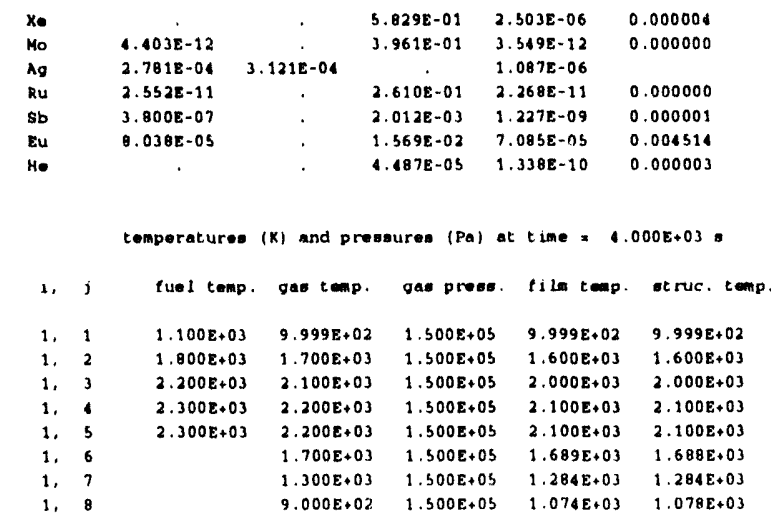

- lement masses $(\mathrm{kg})$ in all cells at time $=4.000 \mathrm{E}+03 \mathrm{~s}$

\begin{tabular}{|c|c|c|c|c|c|c|c|c|c|c|}
\hline - lement & grains & poros & gap & clad & film & bu1k pas & aerasol & ot ructure & total & lost gast \\
\hline ce & $3.212 \mathrm{E}-01$ & $3.011 E-02$ & 8.606E-04 & $3.283 \mathrm{E}-0 \mathrm{~S}$ & $1.029 E-06$ & 7. $3538-05$ & $7.0198-06$ & $3.422 E-05$ & $3.7238-01$ & $3.647 E-02$ \\
\hline I & $2.594 E-02$ & $2.367 \mathrm{E}-02$ & $1.1318-04$ & $7.744 E-06$ & $2.4315-07$ & $1.477 E-05$ & 4. $311 \mathrm{E}-06$ & $2.578 E-05$ & $3.178 E-02$ & $1.053 E-02$ \\
\hline H & . & $1.2178-06$ & $3.814 \mathrm{E}-06$ & $4.373 E-06$ & $1.104 E-0 S$ & $6.092 E-04$ & $2.160 \mathrm{E}-08$ & $3.8745-O S$ & $6.684 E-04$ & 5. $381 \mathrm{E}-0 \mathrm{~S}$ \\
\hline Ba & $1.3538-01$ & 4. $347 E-02$ & $1.6108-05$ & $6.480 \varepsilon-08$ & $2.0328-09$ & $9.217 E-08$ & $6.268 \varepsilon-08$ & $7.457 \mathrm{E}-06$ & 1.7A8E-01 & 4. $296 E-05$ \\
\hline 0 & $1.260 \varepsilon+00$ & $6.020 \mathrm{E}-04$ & 4. $810 \mathrm{E}-0 \mathrm{~S}$ & 2. 211E-01 & 8.141E-05 & $4.253 E-03$ & $7.977 E-07$ & $2.9228-04$ & $1.486 E+00$ & $-2.209 E-01$ \\
\hline st & $1.180 \mathrm{E}-01$ & $2.0088-03$ & B. $991 \mathrm{E}-05$ & $1.450 E-07$ & $4.472 E-09$ & $1.835 \mathrm{E}-07$ & $2.0438-07$ & $1.747 \mathrm{E}-05$ & $1.201 \mathrm{E}-01$ & $7.578 \mathrm{E}-05$ \\
\hline $2 r$ & 1.520E-01 & $4.692 \varepsilon-03$ & $1.820 E-0 b$ & 1. $359 \mathrm{E}+00$ & $2.245 E-05$ & $1.072 E-13$ & $4.761 E-11$ & $9.315 E-11$ & $1.81 b E+00$ & $1.087 E-10$ \\
\hline$s n$ & $9.1598-08$ & $7.0028-09$ & $6.745 E-08$ & $1.096 E-02$ & $3.651 \mathrm{E}-07$ & $4.8108-07$ & $1.943 \mathbf{E}-06$ & $7.846 E-05$ & $1.504 \varepsilon-02$ & 1. $734 \mathrm{E}-04$ \\
\hline T. & $5.2218-02$ & $3.732 E-02$ & $2.724 E-07$ & $7.217 E-09$ & $2.2608-09$ & $1.3718-07$ & $4.032 E-08$ & $3.9028-07$ & $8.953 E-02$ & $3.607 E-05$ \\
\hline u & $9.369 \varepsilon+00$ & 1.297E-0S & $1.269 \mathrm{E}-13$ & $4.268 E-16$ & $9.9618-18$ & $2.079 E-16$ & S. $396 \mathrm{E}-1 \mathrm{~S}$ & $3.4018-14$ & $9.369 E+00$ & $3.425 E-14$ \\
\hline $\mathbf{k r}$ & $1.937 \mathrm{E}-02$ & $3.433 E-04$ & $5.989 E-04$ & $4.601 E-06$ & $1.433 \mathrm{E}-0.7$ & $1.126 \varepsilon-05$ & . & $9.432 E-07$ & $2.033 E-02$ & $2.856 \mathrm{E}-02$ \\
\hline$x \in$ & $2.3118-01$ & $4.116 E-03$ & $7.176 E-03$ & $5.488 E-05$ & $1.712 E-06$ & 1. $342 E-04$ & & 1. $125 E-05$ & $2.426 E-01$ & $3.404 E-01$ \\
\hline Mo & $3.741 E-01$ & $2.1938-02$ & $9.3558-13$ & $2.3438-15$ & $7.224 E+17$ & $2.751 E-13$ & $1.490 \mathrm{E}-14$ & $3.687 E-13$ & $3.961 E-01$ & $1.021 E-12$ \\
\hline AD & $7.572 E-20$ & $1.703 E-12$ & $1.467 \varepsilon-13$ & $1.654 E-13$ & $1.6178-13$ & $6.952 E-08$ & $3.587 E+07$ & $1.472 \mathrm{E}-0 \mathrm{~S}$ & $1.514 E \cdot 05$ & $2.618 E-0 S$ \\
\hline Ru & $2.436 \varepsilon-01$ & $1.735 E-02$ & $6.004 E-12$ & $7,930 \mathrm{E}-13$ & $1.455 E-16$ & $2.546 E-16$ & $1.053 \mathrm{E}-13$ & $1.403 E-12$ & $2.610 \mathrm{E}-01$ & $1.596 \mathrm{E}-12$ \\
\hline $\mathbf{s b}$ & $1.883 E-03$ & $1.285 E-04$ & $3.302 \mathrm{E}-08$ & $9.296 \mathrm{E}-10$ & $2.910 \mathrm{E}-11$ & $1.245 E-09$ & $9.541 E-10$ & $9.476 E-08$ & $2.011 E-03$ & $1.9968-07$ \\
\hline Eu & $1.531 E-02$ & $3.415 E-04$ & $2.5398-05$ & $2.030 \mathrm{E}-08$ & $3.681 E-10$ & $1.134 \mathrm{E}-10$ & $2.7298-07$ & $4.2508-06$ & $1.568 \mathrm{E}-02$ & $4.784 E-06$ \\
\hline $\mathrm{He}$ & 1. 145E-06 & $2.275 E-07$ & S. $517 E-07$ & $3.941 \mathrm{E}-09$ & 1. $186 \mathrm{E}-10$ & $9.7128-09$ & & B. $164 E-10$ & $1.9398-06$ & 4. 2948.05 \\
\hline
\end{tabular}

- loment mesoes (kg) in all celle at time $=4.000 \mathrm{E}+03$.

\begin{tabular}{|c|c|c|c|c|c|}
\hline - Lement & lost aero & aero re & initial & bolance & bal/init \\
\hline C: & $7.0208-03$ & . & C. $158 \mathrm{E}-01$ & 4. $3418-07$ & 0.000001 \\
\hline 1 & $4.503 \varepsilon-03$ & . & $6.682 E-02$ & $2.225 \mathrm{E}-07$ & 0.000003 \\
\hline H & $1.898 E-05$ & . & $7.749 E-04$ & $-3.364 E-05$ & 0.043415 \\
\hline Ba & $3.806 \mathrm{E}-05$ & . & $1.789 E-01$ & $-1.108 \varepsilon-07$ & 0.000001 \\
\hline 0 & $5.3498-04$ & . & $1.2668+00$ & $-2.314 E-04$ & 0.000183 \\
\hline sr & $1.0578-04$ & . & $1.203 E-01$ & $2.681 E-0 S$ & 0.000223 \\
\hline $2 r$ & $2.853 E-09$ & & 1.8378 .00 & $-2.138 E-02$ & 0.011641 \\
\hline $8 n$ & $1.8738-0.3$ & $2.125 \mathrm{E}-03$ & $2.244 \mathrm{E}-02$ & $-7.478 E-03$ & 0.333234 \\
\hline T• & $1.662 \mathrm{E}-05$ & & 8. $959 E-02$ & $2.978 E-09$ & 0.000000 \\
\hline $\mathrm{u}$ & $9.185 \mathrm{E}-13$ & . & 9. $369 \varepsilon+00$ & Q. $100 E-13$ & 0.000000 \\
\hline $\mathbf{K r}$ & . & . & 4. $889 E-02$ & $2.101 \varepsilon-07$ & 0.000004 \\
\hline$x$ & $\cdot$ & . & $5.829 E-01$ & $2.503 E-06$ & 0.000004 \\
\hline Mo & $6.045 E-12$ & . & $3.961 E-01$ & $4.860 \varepsilon-12$ & 0000000 \\
\hline$A g$ & $3.350 \mathrm{E}-04$ & $3.751 \varepsilon-04$ & & 1.301E-06 & \\
\hline Ru & $3.303 E-11$ & , & 2.610E-01 & $2.931 E-11$ & 0.000000 \\
\hline sb & 4.64BE-07 & . & $2.012 E-03$ & $1.438 E-09$ & 0.000001 \\
\hline Eu & $1.0218-04$ & . & 1. $569 \mathrm{E}-02$ & 8. $999 E-05$ & 0.005734 \\
\hline He &. & . & 4. 487E-05 & 1. $338 \mathrm{E}-10$ & 0.000003 \\
\hline
\end{tabular}

cemperatures $(K)$ and preneuren $(P a)$ at $t$ ine $=4.200 E+03$.

\begin{tabular}{|c|c|c|c|c|c|}
\hline , & fuel tomp. & gas temp. & gas press. & $t s \ln t a m p$. & struc. tomp. \\
\hline 1. & $1.120 E+03$ & $1.020 \varepsilon+03$ & $1.500 \mathrm{E} * 0 \mathrm{~S}$ & $1.0208 \cdot 03$ & $1.020 \mathrm{E}+03$ \\
\hline 1. & $1.919 E \cdot 03$ & 1. $819 E+03$ & $1.300 \mathrm{E}+05$ & $1.719 E+03$ & $1.719 E+03$ \\
\hline 1. & $2.319 E+03$ & $2.219 E+03$ & $1.500 \varepsilon+0 s$ & $2.119 E+03$ & $2.119 E+03$ \\
\hline 1 . & $2.4198+03$ & $2.319 \varepsilon+03$ & $1.500 \mathrm{E}+0 \mathrm{~S}$ & $2.219 \mathrm{E}+03$ & $2.219 \varepsilon+03$ \\
\hline 1. & $2.419 E+03$ & $2.3198+03$ & $1.5008 \cdot 05$ & $2.219 \mathrm{E}+03$ & $2.219 E+03$ \\
\hline 1. & & $1.780 E+03$ & $\therefore .500 \varepsilon+05$ & $1.7112+03$ & $1.707 E+03$ \\
\hline 1. & & $1.340 E+03$ & $1.500 z+05$ & $1.296 \mathrm{E}+03$ & $1.294 E+03$ \\
\hline 1. & & $9.000 \varepsilon+02$ & $1.500 \mathrm{E} \cdot 0 \mathrm{~S}$ & $1.042 E+03$ & $1.045 E+03$ \\
\hline
\end{tabular}

- loment masses (kg) in all colle at time = $4.200 \mathrm{E}+03$.

\begin{tabular}{|c|c|c|c|c|c|c|c|c|c|c|}
\hline lement & $\begin{array}{l}\text { grauns } \\
3.193 \varepsilon-01\end{array}$ & $\begin{array}{l}\text { pores } \\
\text { S.109E-02 }\end{array}$ & $\begin{array}{l}\text { gap } \\
9.004 E-04\end{array}$ & $\begin{array}{l}\text { clad } \\
4.40 E-06\end{array}$ & t11: & $\begin{array}{l}\text { bulk gas } \\
1.158 E-05\end{array}$ & $\begin{array}{l}\text { aeronol } \\
\text { C.20sE-07 }\end{array}$ & $\begin{array}{l}\text { at ructurs } \\
2.577 \mathrm{E}-06\end{array}$ & $\begin{array}{l}\text { total } \\
\text { 3.713E-02 }\end{array}$ & $\begin{array}{l}\text { loot gas } \\
3.7358-02\end{array}$ \\
\hline 1 & $2.482 E-02$ & $2.667 \varepsilon-02$ & $1.721 \mathrm{E}-04$ & $3.015 E-07$ & $1.680 \mathrm{E}-00$ & $1.060 E-06$ & $2.735 \mathrm{E}-07$ & $1.242 E-06$ & S. $166 \varepsilon-02$ & $1.061 E-02$ \\
\hline H & & 1. $228 \varepsilon-06$ & $3.866 \varepsilon-06$ & 4. 345E-06 & 1. $092 \varepsilon-05$ & $6.0608-04$ & $2.3558-09$ & $3.873 \varepsilon-05$ & $6.6518-04$ & $3.928 E-0 b$ \\
\hline Ba & $1.424 E-01$ & $3.6408-02$ & 1.950E.03 & $4.962 E-09$ & $1.680 E-10$ & $8.514 E-09$ & $6.771 \mathrm{E}-09$ & $7.450 \mathrm{E}-06$ & 1. $788 \varepsilon-01$ & $0.138 \mathrm{E}-O S$ \\
\hline 0 & $1.260 \varepsilon+00$ & $6.1355-04$ & $4.800 \mathrm{E}-0 \mathrm{~S}$ & $2.534 E-01$ & $7.855 E-05$ & $4.0618-03$ & $4.1888-07$ & $2.8148-04$ & $1.518 E+00$ & $-2.332 E-01$ \\
\hline $\mathbf{s r}$ & $1.1798-01$ & $2.07 \& E-03$ & B.SS7E-0S & B. $880 \varepsilon-08$ & 2. $924 E-09$ & $1.223 E-07$ & $1.198 E-07$ & $1,903 \mathrm{E}-05$ & $1.201 \varepsilon-01$ & Q.015E-0S \\
\hline $2 r$ & 4.511E-01 & $5.5558-03$ & $1.820 \mathrm{E}+0 \mathrm{~s}$ & $1.359 E+00$ & $2.245 \mathrm{E}-0.5$ & $2.0608-11$ & 3.647 E-09 & 6. $363 \mathrm{E}-09$ & $1.815 \varepsilon+00$ & $8.421 \pi-10$ \\
\hline
\end{tabular}




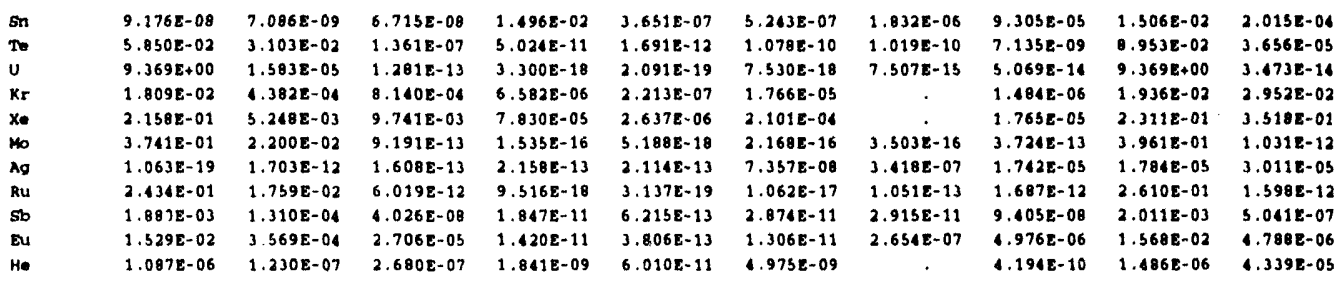

- lement masses $(\mathrm{kg})$ in all cells at time $=4.200 \varepsilon+03=$

\begin{tabular}{|c|c|c|c|c|c|}
\hline $\begin{array}{l}\text { - } 1 \text { ement } \\
c a\end{array}$ & $\begin{array}{l}\text { lost aero } \\
7.091 \mathrm{E}-03\end{array}$ & aero & $\begin{array}{l}\text { initial } \\
4.158 \mathrm{E}-01\end{array}$ & $\begin{array}{l}\text { balance } \\
1.457 E-08\end{array}$ & $\begin{array}{l}\text { bal/init } \\
0.000000\end{array}$ \\
\hline 1 & $4.548 x-03$ & . & $6.682 \mathrm{E}-02$ & $1.8318-07$ & 0.000003 \\
\hline$H$ & $1.929 \mathrm{E}-03$ & & $7.749 E-04$ & $-5.118 \varepsilon-05$ & 0.066055 \\
\hline Ba & $3.990 \mathrm{E}-05$ & . & t.789E-01 & $-1.778 \mathrm{E}-07$ & 0.000001 \\
\hline o & $5.818 \varepsilon-04$ & . & $1.266 \mathrm{E}+00$ & $-3.354 E-04$ & 0.000265 \\
\hline $\mathrm{sr}$ & $1.1048-04$ & . & $1.203 \varepsilon-01$ & $2.812 \mathrm{E}-05$ & 0.000236 \\
\hline $2 r$ & $1.442 \mathrm{E}-07$ & . & $1.837 E+00$ & $-2.138 E-02$ & 0.011641 \\
\hline$s \pi$ & $2.154 \mathrm{E}-03$ & $2.449 \mathrm{E}-03$ & $2.244 \mathrm{E}-02$ & $-7.478 E-03$ & 0.333229 \\
\hline Te & $1.694 \mathrm{E}-05$ & . & $0.959 E-02$ & $2.9578-09$ & 0.000000 \\
\hline$u$ & 1. $005 \mathrm{E}-12$ & . & $9.369 \mathrm{E}+00$ & $1.315 E-12$ & 0.000000 \\
\hline $\mathbf{k r}$ & . & . & $4.889 z-02$ & $-2.490 E-07$ & 0.000005 \\
\hline$x_{0}$ & & . & $5.829 E-01$ & $-2.961 E-06$ & 0.000005 \\
\hline Mo & $6.116 \mathrm{E}-12$ & . & $3.961 \mathrm{E}-01$ & $4.900 \mathrm{E}-12$ & 0.000000 \\
\hline Ag & $3.856 \mathrm{E}-04$ & $4.321 \mathrm{E}-06$ & & $1.418 E-06$ & \\
\hline Ru & $4.120 E-11$ & . & $2.610 \mathrm{E}-01$ & $3.775 E-11$ & 0.000000 \\
\hline $5 b$ & $4.722 E-07$ & . & $2.012 \mathrm{E}-03$ & $1.449 E-09$ & 0.000001 \\
\hline Eu & $1.230 \mathrm{E}-04$ & . & $1.569 \mathrm{E}-02$ & $1.1168-04$ & 0.007108 \\
\hline He & & . & $4.487 \mathrm{E}-05$ & $1.3388-10$ & 0.000003 \\
\hline
\end{tabular}

tomperatures $(\mathrm{K})$ and presenres (Pa) at time = 4.400E+03.

\begin{tabular}{|c|c|c|c|c|c|}
\hline J & fuel temp. & gas temp. & gas press. & film temp. & at ruc temp \\
\hline 1 & $1.160 \mathrm{E}+03$ & $1.040 \varepsilon+03$ & $1.500 \mathrm{E}+05$ & $1.0408+03$ & $1.040 E+03$ \\
\hline 2 & $2.039 E+03$ & $1.939 \mathrm{E}+03$ & $1.500 E+05$ & $1.839 \mathrm{E}+03$ & $1.839 \mathrm{E}+03$ \\
\hline 3 & $2.439 E+03$ & $2.339 \mathrm{E}+03$ & $1.500 E+05$ & $2.2398+03$ & $2.239 \mathrm{E}+03$ \\
\hline 4 & $2.539 \mathrm{E}+03$ & $2.439 \varepsilon+03$ & $1.500 E+05$ & $2.339 \mathrm{E}+03$ & $2.339 E+03$ \\
\hline 5 & $2.539 E+03$ & $2.439 E+03$ & $1.500 \varepsilon+05$ & $2.3398+03$ & $2.339 E+03$ \\
\hline 6 & & 1. $860 E+03$ & $1.500 E+05$ & 1. $756 \mathrm{E}+03$ & $1.750 E+03$ \\
\hline 7 & & $1.380 E+03$ & $1.500 \mathrm{E}+0 \mathrm{~S}$ & $1.317 \varepsilon+03$ & $1.314 E+03$ \\
\hline & & $9.000 \mathrm{E}+02$ & $1.500 \varepsilon+05$ & $1.014 \varepsilon+03$ & $1.017 \mathrm{E}+03$ \\
\hline
\end{tabular}

- lement massas $(\mathrm{kg})$ in all cells at $\mathrm{t}$ ime $=4.400 \mathrm{E}+03 \mathrm{~s}$

\begin{tabular}{|c|c|c|c|c|c|c|c|c|c|c|}
\hline - Iement & grains & pores & gap & clad & tilm & bulk gas & $\begin{array}{l}\text { aerosol } \\
1.067 E-06\end{array}$ & $\begin{array}{l}\text { otructure } \\
6.971 E-06\end{array}$ & $\begin{array}{l}\text { total } \\
3.7058-01\end{array}$ & $\begin{array}{l}108 t \text { gas } \\
3.814 \mathrm{E}-02\end{array}$ \\
\hline I & $\begin{array}{l}3.157 E-01 \\
2.168 E-02\end{array}$ & $\begin{array}{l}5.372 E-02 \\
2.9468-02\end{array}$ & $\begin{array}{l}1.063 \mathrm{E}-03 \\
3.491 \mathrm{E}-04\end{array}$ & $\begin{array}{l}4.769 \mathrm{E}-06 \\
1.356 \mathrm{E}-06\end{array}$ & $\begin{array}{l}1.759 \mathrm{E}-07 \\
\text { 4. } 986 \mathrm{E}-08\end{array}$ & $\begin{array}{l}1.322 \mathrm{E}-0 \mathrm{~S} \\
3.160 \mathrm{E}-06\end{array}$ & $\begin{array}{l}1.067 E-06 \\
\text { B.502E-07 }\end{array}$ & $\begin{array}{l}6.9711 E-06 \\
\text { S.275E-06 }\end{array}$ & $\begin{array}{l}3.705 E-01 \\
3.151 E-02\end{array}$ & $1.071 E-02$ \\
\hline H & . & $1.242 E-06$ & $3.8948-06$ & $4.310 \mathrm{E}-06$ & $1.079 \mathrm{E}-05$ & $6.022 \varepsilon-04$ & $3.404 E-09$ & $3.074 \mathrm{E}-05$ & $6.612 \mathrm{E}-04$ & $2.643 \mathrm{E}-0 \mathrm{~S}$ \\
\hline $\mathrm{Ba}$ & $1.488 \mathrm{E}-01$ & $2.997 \mathrm{E}-02$ & $2.750 \mathrm{E}-05$ & $1.017 \mathrm{E}-09$ & $3.752 \varepsilon-11$ & $2.401 E-09$ & $2.969 \varepsilon-09$ & $7.1728-06$ & $1.788 \varepsilon-01$ & $1.468 \mathrm{E}-0 \mathrm{~S}$ \\
\hline 0 & $1.260 \mathrm{E}+00$ & $6.236 \mathrm{E}-04$ & $4.7148-05$ & $2.9198-01$ & $7.481 \mathrm{E}-0 \mathrm{~S}$ & $3.801 E-03$ & $3.872 E-07$ & $2.655 E-04$ & $1.556 \mathrm{E}+00$ & $-2.916 \Sigma-01$ \\
\hline sr & $1.179 \mathrm{E}-01$ & $2.127 \mathrm{E}-03$ & $7.963 \mathrm{E}-05$ & $1.386 \mathrm{E}-07$ & $5.040 \varepsilon-09$ & $2.1348-07$ & $2.229 \mathrm{E}-07$ & $2.225 \Sigma-05$ & $1.201 \mathrm{E}-01$ & B.647E-05 \\
\hline $2 r$ & $4.503 \varepsilon-01$ & $6.405 \mathrm{E}-03$ & 1.817E-05 & $1.359 \mathrm{E}+00$ & $2.24 \leq \varepsilon-05$ & $1.480 \mathrm{E}-10$ & $3.971 \mathrm{E}-0 \mathrm{~B}$ & $9.980 \mathrm{E}-08$ & $1.815 E+00$ & $3.636 \varepsilon-09$ \\
\hline sn & $9.187 E-08$ & $7.188 \mathrm{E}-09$ & $6.691 \mathrm{E}-08$ & $1.496 \mathrm{E}-02$ & $3.6518-07$ & $6.191 \mathrm{E}-07$ & $1.694 \mathrm{E}-06$ & $1.1398-04$ & $1.508 E-02$ & $2,316 E-04$ \\
\hline To & $6.4018-02$ & $2.532 \mathrm{E}-02$ & $2.744 E-07$ & $3.301 \mathrm{E}-10$ & $1.205 \mathrm{E}-11$ & $7.535 E-10$ & $2.060 \mathrm{E}-10$ & $1.790 \mathrm{E}-09$ & $8.953 \mathrm{E}-02$ & $3.658 \mathrm{E}-05$ \\
\hline u & $9.369 E+00$ & $1.903 E-05$ & $1.3358-13$ & $1.486 \mathrm{E}-17$ & $3.211 \mathrm{E}-19$ & $1.845 E-17$ & $1.0858-14$ & $9.356 \mathrm{E}-14$ & $9.369 E+00$ & $3.554 \mathrm{E}-11$ \\
\hline $\mathrm{Kr}$ & $1.625 \mathrm{E}-02$ & $5.307 \mathrm{E}-04$ & $1.055 E-03$ & $8.973 E-06$ & $3.3018-07$ & $2.691 E-05$ & & $2.273 E-06$ & $1.787 E-02$ & $3.101 \mathrm{E}-0.2$ \\
\hline$x_{\bullet}$ & $1.960 \mathrm{E}-01$ & $6.352 \mathrm{E}-03$ & $1,262 \mathrm{E}-02$ & $1.067 \mathrm{E}-04$ & $3.931 \mathrm{E}-06$ & $3.200 \mathrm{E}-04$ & & $2.703 E-05$ & $2.134 E-01$ & $3.695 \mathrm{E}-01$ \\
\hline Mo & $3.740 \varepsilon-01$ & $2.205 \mathrm{E}-02$ & $8.043 E-13$ & $5.553 \mathrm{E}-16$ & $2.047 E-17$ & $3.630 \mathrm{E}-16$ & $9.750 \mathrm{E}-16$ & $3.811 E-13$ & $3.961 \mathrm{E}-01$ & $1.049 \mathrm{E}-12$ \\
\hline Ag & $1.562 E-19$ & $1.703 \varepsilon-12$ & $1.9388-13$ & $2.882 \mathrm{E}-13$ & $2.824 \mathrm{E}-13$ & $8.049 E-08$ & $3.255 \mathrm{E}-07$ & $2.128 \mathrm{E}-05$ & $2.169 \mathrm{E}-0 \mathrm{~S}$ & $3.393 \mathrm{E}-05$ \\
\hline $\mathrm{Ru}$ & $2.432 \mathrm{E}-01$ & $1.776 \mathrm{E}-02$ & $6.099 \mathrm{E}-12$ & $3.779 \mathrm{E}-17$ & $1.586 \mathrm{E}-18$ & $3.612 E-17$ & $8.5908-14$ & $2.143 E-12$ & $2.610 \mathrm{E}-01$ & $1.600 E-12$ \\
\hline sb & $1.878 \mathrm{E}-03$ & $1.331 \mathrm{E}-04$ & $6.446 \varepsilon-08$ & $3.906 \mathrm{E}-11$ & $1.436 \mathrm{E}-12$ & $6.972 \mathrm{E}-11$ & $5.253 \mathrm{E}-11$ & $9.318 \mathrm{E}-08$ & $2.011 \mathrm{E}-03$ & $3.0658-07$ \\
\hline Eu & $1.527 \mathrm{E}-02$ & $3.716 \mathrm{E}-04$ & $2.9768-05$ & $7.485 \mathrm{E}-11$ & $2.4298-12$ & $8.525 \mathrm{E}-11$ & $2.0095-07$ & $6.098 \mathrm{E}-06$ & $1.5608-02$ & $4.791 E-06$ \\
\hline$H$ & $9.031 \mathrm{E}-07$ & $8.783 \mathrm{E}-08$ & $1.745 E-07$ & $1.567 \mathrm{E}-09$ & $5.617 \mathrm{E}-11$ & $4.708 E-09$ & . & $3.984 \varepsilon-10$ & $1.172 E-06$ & $4.3708-05$ \\
\hline
\end{tabular}

\begin{tabular}{|c|c|c|c|c|c|}
\hline 1 ement & last aero & aero sce & intial & belance & bal/2nit \\
\hline cs & $7.173 E-03$ & & $4.1388-01$ & $-4.177 \mathrm{E}-07$ & 0.000001 \\
\hline 1 & $4.608 E-03$ & . & $6.682 \mathrm{E}-02$ & $1.029 \varepsilon-07$ & 0.000002 \\
\hline H & $1.961 \mathrm{E}-05$ & . & $7.749 \mathrm{E}-0$. & $-6.762 \mathrm{E}-05$ & 0.087273 \\
\hline Ba & $4.028 E-05$ & . & $1.789 \varepsilon-01$ & $-2.295 E-07$ & 0.000001 \\
\hline 0 & $6.216 \mathrm{E}-04$ & . & $1.266 \mathrm{E}+00$ & $-4.240 \mathrm{E}-04$ & 0.000333 \\
\hline$s r$ & $1.286 \mathrm{E}-04$ & . & $1.203 \mathrm{E}-01$ & $3.053 \mathrm{E}-05$ & 0.000254 \\
\hline $2 r$ & $1.455 E-06$ & . & $1.837 \mathrm{E}+00$ & $-2.138 E-02$ & 0.011641 \\
\hline sn & $2.392 \mathrm{E} \cdot 03$ & $2.738 E-03$ & $2.244 E-02$ & $-7.478 E-03$ & 0.333226 \\
\hline Te & $1.695 \mathrm{E}-05$ & . & 8. $959 \mathrm{E}-02$ & $2.958 \mathrm{E}-09$ & 0.000000 \\
\hline$u$ & 2.077 E- 12 & . & $9.369 E+00$ & $2.030 E-12$ & 0.000000 \\
\hline $\mathbf{k} \boldsymbol{x}$ & . & . & 4. $889 \mathrm{E}-02$ & $-1.002 \varepsilon-06$ & 0.000021 \\
\hline$x_{\theta}$ & . & . & $5.829 \mathrm{E}-01$ & $-1.192 E-0 S$ & 0.000020 \\
\hline Mo & $6.163 \varepsilon-12$ & . & $3.961 \mathrm{E}-01$ & 4. $915 \Sigma-12$ & 0.000000 \\
\hline Ag & $4.290 \mathrm{E}-04$ & $4.831 \mathrm{E}-04$ & . & $1.473 E-06$ & \\
\hline Ru & $4.826 E-11$ & 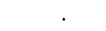 & $2.610 \mathrm{E}-01$ & 4. $525 E-11$ & 0.0000 \\
\hline sto & $0.758 E-07$ & . & $2.012 E-03$ & $1.452 \mathrm{E}-09$ & 0.000001 \\
\hline Du & $1.404 \varepsilon-04$ & . & $1.569 \mathrm{E}-02$ & $1.3008-04$ & 0.00828 \\
\hline He & . & . & $4.467 \mathrm{E}-05$ & 1. $338 \mathrm{E}-10$ & 0.0000 \\
\hline
\end{tabular}




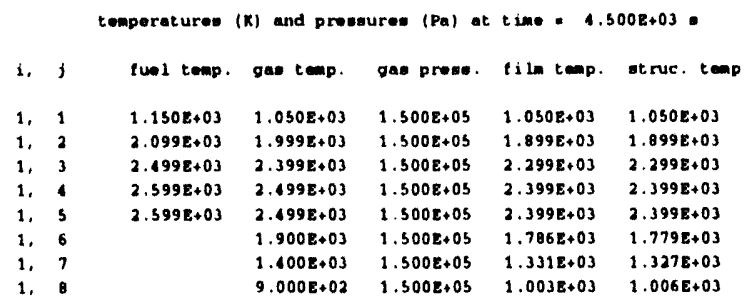

-1 lement masues (kg) in oll collo at tine = 4.500E+03.

\begin{tabular}{|c|c|c|c|c|c|c|c|c|c|c|}
\hline $\begin{array}{l}\text { element } \\
\text { Ca }\end{array}$ & $\begin{array}{l}\text { grains } \\
3.129 E-01\end{array}$ & $\begin{array}{l}\text { pores: } \\
5.586 E-0\end{array}$ & $\begin{array}{l}\text { gap } \\
1.203 E-0\end{array}$ & $\begin{array}{l}\text { clad } \\
\text { c.841E-08 }\end{array}$ & film & $\begin{array}{l}\text { bulk gas } \\
1.381 E-05\end{array}$ & $\begin{array}{l}\text { aerosol } \\
1.5580 .06\end{array}$ & $\begin{array}{l}\text { otructure } \\
1.1942-05\end{array}$ & $\begin{array}{l}\operatorname{total} \\
3.700 \mathrm{E}-01\end{array}$ & $\begin{array}{l}\text { lost gas } \\
3.0518-02\end{array}$ \\
\hline 1 & $1.910 \varepsilon-02$ & $3.175 \mathrm{E}-02$ & C. $918 \mathrm{E}-04$ & $1.919 \varepsilon-06$ & $7.417 z-08$ & C. $725 \varepsilon-06$ & $1.305 E-06$ & $9.9968-06$ & $5.1368-02$ & $1.0802-02$ \\
\hline H & . & 1. 269E-06 & $.901 E-06$ & 4. 289E-06 & $1.072 E-03$ & $6.002 E-04$ & $3.0738-09$ & $3.8758-03$ & $6.591 x-04$ & $2.0548-05$ \\
\hline Ba & $1.501 E-01$ & $2.867 E-02$ & $3.180 \mathrm{E}-0 \mathrm{~S}$ & $1.080 \mathrm{~B}-09$ & C. $1818-11$ & $2.682 \varepsilon-09$ & $3.093 E-09$ & $7.0328-06$ & $1.78 B E-01$ & 1.1788-0s \\
\hline$\circ$ & $1.260 \varepsilon+00$ & $6.282 E-04$ & $4.646 \mathrm{E}-05$ & $3.1388-01$ & $7.2598-05$ & $3.645 E-03$ & $3.7828-07$ & $2.3578-04$ & $1.378 \mathrm{E}+00$ & $-3.134 E-01$ \\
\hline $\mathbf{s r}$ & $1.1788-01$ & $2.138 \mathrm{E}-03$ & $7.598 \mathrm{E}-05$ & 1.585E-07 & $6.072 E-09$ & $2.588 E-07$ & $2.9038-07$ & $2.475 E-03$ & $1.201 \mathrm{E}-01$ & $9.032 \mathrm{E}-0 \mathrm{~s}$ \\
\hline $2 r$ & C.500E-01 & $6.670 \mathrm{E}-03$ & $1.814 E-05$ & $1.3598+00$ & $2.245 \varepsilon-05$ & $3.559 E-10$ & $7.468 E-08$ & $2.688 E-07$ & $1.815 E+00$ & $1.295 E-08$ \\
\hline sn & $3.202 E-08$ & $7.264 E-09$ & $6.664 E-08$ & $1.496 \mathrm{E}-02$ & $3.651 \mathrm{E}-07$ & $6.647 \varepsilon-07$ & $1.6318-06$ & $1.2558-04$ & $1.309 z-02$ & $2.4738-04$ \\
\hline T* & $6.496 E-02$ & $2.457 E-02$ & $6.105 E-07$ & $1.151 E-09$ & $4.408 E-11$ & $2.776 \mathrm{E}-09$ & $7.475 E-10$ & $4.714 \varepsilon-09$ & $8.953 E-02$ & $3.6612-05$ \\
\hline$u$ & $9.369 E+00$ & $2.076 \mathrm{E}-03$ & $1.422 \mathrm{E}-13$ & $2.7918-17$ & $7.0038-19$ & $2.4438-17$ & $9.4328-15$ & $1.236 E-13$ & $9.3698+00$ & $3.608 E-14$ \\
\hline $\mathbf{k r}$ & $1.537 \mathrm{E}-02$ & $5.353 E-04$ & $1.076 \mathrm{E}-03$ & $9.123 \mathrm{E}-06$ & $3.5288-07$ & $2.908 E-05$ & . & $2.4638-06$ & $1.7028-02$ & $3.1068-02$ \\
\hline$x_{\bullet}$ & $1.835 E-01$ & $6.4078-03$ & $1.287 \mathrm{E}-02$ & $1.085 E-04$ & 4. 2018-06 & $3.458 \mathrm{E}-04$ & $\cdot$ & $2.9308-05$ & $2.0338-01$ & $3.796 \mathrm{E}-01$ \\
\hline Mo & $3.740 E-01$ & $2.207 E-02$ & $8.4978-13$ & $1.263 \mathrm{E}-15$ & $1.802 E-17$ & $2.0348-15$ & $2.058 E-15$ & $3.948 \mathrm{E}-13$ & $3,9618-01$ & $1.069 E-12$ \\
\hline$A g$ & $1.909 E-19$ & $1.706 \varepsilon-12$ & $2.185 E-13$ & $3.3638-13$ & $3.296 \mathrm{E}-13$ & $8.558 \mathrm{E}-08$ & $3.1628-07$ & $2.3478-05$ & $2.388 z-0 b$ & $3.583 z-05$ \\
\hline Ru & $2.4318-01$ & $1.782 \varepsilon-02$ & $6.259 \mathrm{E}-12$ & $7.3868-17$ & $3.418 z-18$ & $1.2218-16$ & $6.189 \mathrm{E}-11 \mathrm{C}$ & $2.355 E-12$ & $2.6108-01$ & $1.6028-12$ \\
\hline sb & $1.877 E-03$ & $1.3408-04$ & $8.041<-08$ & $3.567 z-11$ & $2.148 E-12$ & $1.073 \varepsilon-10$ & $7.182 E-11$ & 9. $300 E-00$ & $2.0118-03$ & $3.0038-07$ \\
\hline Eu & $1.326 \mathrm{E}-02$ & $3.792 \mathrm{E}-04$ & $3.1528-05$ & $1.667 E-10$ & S. $979 E-12$ & 2. $116 E-10$ & $1.3158-07$ & $6.581 z-06$ & $1.369 \mathrm{E}-02$ & $4.7948-06$ \\
\hline H॰ & $7.9008-07$ & $7.927 \mathrm{E}-08$ & $1.5268-07$ & $1.487 \varepsilon-09$ & $5.612 E-11$ & $4.741 E-09$ & & $4.0238-10$ & $1.0298-06$ & A. $305 E-05$ \\
\hline
\end{tabular}

-lemont masses (kg) in all celle at time $=4,300 \varepsilon+03$.

\begin{tabular}{|c|c|c|c|c|c|}
\hline lement & $\begin{array}{l}\text { loot wero } \\
7.246 E-03\end{array}$ & aero oce & $\begin{array}{l}\text { initial } \\
\text { 4.158E-01 }\end{array}$ & $\begin{array}{c}\text { bolance } \\
-6.125 E-07\end{array}$ & $\begin{array}{c}\text { bal / init } \\
0.000002\end{array}$ \\
\hline I & $4.668 \varepsilon-03$ & . & $6.682 E-02$ & $2.242 E-0 \theta$ & 0.000000 \\
\hline$H$ & $1.980 \mathrm{E}-0 \mathrm{~S}$ & . & $7.749 \mathrm{E}-04$ & $-7.543 E-05$ & 0.097345 \\
\hline Ba & $4.041 E-05$ & . & $1.7898-01$ & $-2.473 E-07$ & 0.000001 \\
\hline 0 & $6.399 E-04$ & . & $1.266 \mathrm{E}+00$ & $-4.618 \mathrm{E}-04$ & 0.000365 \\
\hline $8 \mathbf{r}$ & $1.3858-04$ & & $1.203 E-01$ & $3.3018-05$ & 0.000274 \\
\hline $2 r$ & $3.3308-06$ & . & $1.837 E+00$ & $-2.1388-02$ & 0.011639 \\
\hline sn & $2.497 \mathrm{E}-03$ & $2.069 E-03$ & $2.244 E-02$ & $-7.478 E-03$ & 0.333225 \\
\hline Te & $1.698 z-03$ & 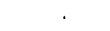 & $8.959 \varepsilon-02$ & $2.9608-09$ & 0.000000 \\
\hline$u$ & $2.425 E-12$ & . & $9.369 E+00$ & $2.419 E-12$ & 0.000000 \\
\hline $\mathrm{xr}_{\mathrm{r}}$ & . & . & C. $8898-02$ & $-1.453 E-06$ & 0.000030 \\
\hline xe & . & . & 5. $829 E-01$ & $-1.728 E-05$ & 0.000030 \\
\hline Mo & $6.2198-12$ & . & $3.961 \mathrm{E}-01$ & $4.928 E-12$ & 0.000000 \\
\hline$A g$ & $4.481 \mathrm{E}-04$ & $5.064 E-04$ & & $1.4908-06$ & \\
\hline Ru & $5.077 E-11$ & . & $2.6108-01$ & $4.7948-11$ & 0.000000 \\
\hline sb & $1.7858-07$ & . & $3.012 \varepsilon-03$ & $1.453 \mathrm{E}-09$ & 0.000001 \\
\hline Eu & $1.160 E-04$ & . & $1.569 \mathrm{E}-02$ & $1.3608-04$ & 0.008665 \\
\hline He & & & $4.487 E-05$ & 1. $338 \mathrm{E}-10$ & 0.000003 \\
\hline
\end{tabular}




\section{DISTRIBUTION:}

U. S. Nuclear Regulatory Commission (4) Office of Nuclear Regulatory Regulation

Attn.:

R. Barrett, OWFN

J. H. Flack, NLS324

L. Soffer, NLN324

A. C. Thadani, OWFN 8 E 2

Washington, D.C. 20555

U.S. Nuclear Regulatory Commission (10)

Office of Nuclear Regulatory Research

Attn.:

E. S. Beckjord, NLS007

F. Eltawila, NLN344

N. Grossman, NLN344

T. L. King, NLN370

R. Y. Lee, NLN344

R. L. Palla, Jr., OWFN 10 E 4

A. M. Rubin, NLN344

B. W. Sheron, NLN369

T. P. Speis, NLS007

C. G. Tinkler, NLN344

Washington, D.C. 20555

U. S. Nuclear Regulatory Commission Office of ACRS

Attn.: M. D. Houston, PHIL P-315

Washington, D.C. 20555

U. S. Nuclear Regulatory Commission

Division of Technical Information and Document Control

7920 Norfolk Avenue

Bethesda, MD 20014

U.S. Department of Energy (3)

Albuquerque Operations Office

P.O. Box 5400

Attn.:

R. N. Holton

J. A. Morley

J. R. Roeder

Albuquerque, NM 87185

U.S. Department of Energy

Idaho Operations Office

785 DOE Place

Attn.: W. H. Rettig

Idaho Falls, ID 83401-1134

\section{ABB/CE}

1000 Prospect Mill Road

CEP 9612-2207

Attn.: R. Schneider

Winsor, CT 06095
Argonne National Laboratory

9700 South Cass Avenue

Attn.: B. Spencer

Argonne, IL 60439

Battelle Columbus Laboratory (2)

505 King Avenue

Attn.: C. Alexander

C. Ventresca

Columbus, $\mathrm{OH} 43201$

Battelle Pacific Northwest Laboratory

Reactor Systems, Fuels \& Matls. P8-35

P.O. Box 999

Attn.: F. E. Panisko

Richland, WA 99352

Brookhaven National Laboratory

$130 \mathrm{BNL}$

Attn.: T. Pratt

Upton, NY 11973

Electric Power Research Institute

P.O. Box 10412

3412 Hillview Avenue

Altn.: M. Merilo

Palo Alto, CA 94303

Energy Research 6290 Montrose Rd.

Attn.: M. Khatib-Rahbar

Rockville, MD 20852

Fauske and Associates

16W070 West 83rd St.

Attn.: R. J. Hammersly

Burr Ridge, IL 60521

General Atomics

P. O. Box 85608

Attn.: S. Inamati

San Diego, CA 92138-5608

G. E. Knolls Atomic Power Lab

Box 1072

Attn.: J. Conine, D2-221

Schenectady, NY 12501

Idaho National Engineering Laboratory

EG\&G Idaho, Inc.

Willow Creek Building, W-3

P.O. Box 1625

Attn.: C. M. Allison

Idaho Falls, ID 83415 
International Technical Services

420 Lexington Avenue

Attn.:

P. Abramson

New York, New York 10170

Los Alamos National Laboratory (3)

P.O. Box 1663

Attn.: F. Dearing

L. Trocki

B. Boyack

Los Alamos, NM 87545

Massachusetts Institute of Technology (2)

Nuclear Engineering Dept.

77 Massachusetts Avenue

Attn.: M. Kazimi

N. Todreas

Cambridge, MA 02139

Oak Ridge National Laboratory (7)

P.O. Box Y

Attn.:
E. Beahm
T. Kress
R. Lorenz
M. Osborne
B. Patton
R. Taleyarkhan
A. L. Wright

Oak Ridge, TN 37830

PLG Inc.

191 Calle Magdalena

Suite 240

Attn.: D. Buttermer

Encunitas, CA 92024

Rensselaer Polytechnic Institute (2) Department of Nuclear Engineering and Engineering Physics

Attn.: R. T. Lahey Jr. M. Podowski

Troy, NY 12180-3590
Rice University

Department of Chemistry 6100 Main Street

Attn.: J. L. Margrave

Houston, TX 77251

Risk Management Associates 2309 Dietz Farm Road, NW

Attn.: P. Bieniarz

Albuquerque, NM 87107

Stone and Webster

245 Summer Street

Attn.: J. Metcalf, MS 245-2

Boston, MA 02107

University of California, Berkeley (3)

Attn.: L. Brewer

D. Olander

S. Prussin

Berkeley, CA 94720

University of California, Los Angeles

Nuclear Energy Laboratory

405 Hilgaard Avenue

Attn.: I. Catton

Los Angeles, CA 90024

University of Maryland

Nuclear Engineering Department

Attn.: F. Munno

College Park, MD 20742

Westinghouse Bettis Atomic Laboratory

P.O. Box 79

Attn.: J. W. Wolfe

ZAP 34N

West Mifflin, PA 15122-0079 


\section{FOREIGN DISTRIBUTION:}

\section{AECL CANDU \\ Sheridan Park Research Community \\ 2251 Speakman Avenue \\ Attn.: V. J. Nath \\ Mississauga, Ontario L5K 1 B2 \\ CANADA}

AECL Research (4)

Chalk River Research Laboratories

Attn.: L. N. Carlucei

D. S. Cox

L. W. Dickson

R. S. Dickson

Chalk River, Ontario KOJ 1 JO

CANADA

AECL Research (2)

Whiteshell Laboratories

Attn.: S. R. Mulpuru

L. A. Simpson

Pinawa, Manitoba ROE 1LO

CANADA

AERE Hanwell (4)

Didcot

Attn.:

R. G. J. Ball

N. E. Beatham

M. A. Mignanelli

A. L. Nichols

Oxfordshire OX11 ORA

UNITED KINGDOM

Cadarache Center for Nuclear Studies (5)

Attn.:

B. Andre

P. Dumaz

J. Leveque

A. Meyer-Heine

F. Serre

F-13108 Saint Paul-Lez-Durance Cedex

FRANCE

Consejo de Seguridad Nuckan

SOR Angela de la Cruz No. 3

Attn.: J. Bagues

28056 Madrid

SPAIN

Consijo de Seguridad Nuclear

Justo Dorado 11

Attn.: J. A. Martinez

28040 Madrid

SPAIN
Committee on the Use of Atomic Energy for Peaceful Purposes

69 Shipchenski

Prokhod Blvd.

Attn.: Y. Yanev

1574, Sofia

BULGARIA

Director Research, Science Education CEC

Rue De La Loi 200

Attn.: B. Tolley

1049 Brussels

BELGIUM

Finnish Centre for Radiation and Nuclear Safety

Department of Nuclear Safety

P.O. Box 268

Attn.: R. Pollanen

SF-00101 Helsinki

FINLAND

ENEL - CRTN

Via Monfalcone 15

Attn.: E. Borioli

20132 Milan

ITALY

E. T. S. Ingenieros Industriales Jost Gutierrez Abascal, 2

Attn.: A. Alonso

28006 Madrid

SPAIN

Hungarian Atomic Energy Commission

H-1374 Budapest, P.O. Box 565

Attn.: S. Elo

Budapest

HUNGARY

Institut de Protection et de Surete Nucleaire

CEN/FAR - B. P. No. 6

F-92265

Fontenay-aux-Roses

Attn.:M. LiVolant

Cedex

FRANCE 
Institute of Nuclear Energy Research

P.O. Box 3

Attn.: Sen-l Chang

Lung-Tan

TAIWAN 325

Japan Atomic Energy Research Institute (2)

Tokai-mura

Naku-gun

Attn.: Y. Maruyama

J. Sugimoto

Ibaraki-ken, 319-11

JAPAN

JRC Ispra Establishment (6)

Thermodynamics and Radiation Physics

Attn.: J. Capitao

P. Fasoli-Stella

E. Hontanon

A. V. Jones

I. Shepherd

Y. Drossinos

1-201020 Ispra (Varese)

ITALY

Jozef Stefan Institute

Jamova 39

Attn.: B. Mavko

61111 Ljubljana

SLOVENIA

Kernforschungszentrum Karlsruhe (2)

P.O. Box 3640

Attn.:

B. Kuczera

P. Hofmann

75 Karlsruhe

GERMANY

Korea Advanced Energy Research Institute

P.O. Box 7

Daeduk-Danji

Attn.: Hee-Dong Kim

Taejeon 305-353

KOREA

Netherlands Energy Research Foundation (5)

P.O. Box 1

Attn.:
A. S. Booij
E. Cordfunke
M. E. Huntelaar
R. Konings
P. Stoop

1755 ZG Petten (NH)

THE NETHERLANDS
Nuclear Power Engineering Center

Fujitakanko Building

17-1, 3-Chrome, Toranomon, Minato-Ku

Attn.: Kenji Takumi

Tokyo, 105

JAPAN

Nuclear Electric (3)

Berkeley Nuclear Laboratory, Berkeley

Attn.: C. Chapman

J. Eccles

J. Gwyther

Gloucestershire GL13 9PB

UNITED KINGDOM

Nucleare e della Protezione Sanitaria (DISP)

Ente Nazionnle Energie Altemative (ENEA)

Viale Regina Margherita, 125

Casella Postale M. 2358

Attn.: G. Petrangeli

I-00100 Roma A. D.

ITALY

Nuclear Regulatory Authority

Slovak Republic

Bajkalska 27

Attn.: J. Misak

82721 Bratislave

SLOVAK REPUBLIC

Nuclear Research Institute

Attn.: A. Rydl

25068 Rez

CZECH REPUBLIC

Nuclear Safety Institute (3)

Russian Research Center KI

1 Kurchatov Square

Attn.: V. Asmolov

E. G. Basanski

V. Demin

123182 Moscow

RUSSIA

N. V. Kema

P.O. Box 9035

Attn.: P. Kloeg

6800 ET Arnhem

THE NETHERLANDS 
Ontario Hydro (2)

700 University Avenue

Attn.: F. C. Iglesias

O. Akalin

Toronto, Ontario M5G 1 X6

CANADA

Paul Scherrer Institute

Attn.: P. Hosemann

$\mathrm{CH}-5232$ Villigen, PSI

SWITZERLAND

Polytechnical University of Madrid

Nuclear Engineering Department

Jose Gutierrez Abascal, 2

Attn.: A. Alonzo-Santos

28006 Madrid

SPAIN

Power Reactor Nuclear Fuel Development Corporation (PNC)

9-13, 1-Chome

Akasaka

Attn.: A. Watanabe

Minato-Ku, Tokyo

JAPAN

Reactor Centrum Nederland

Attn.: K. J. Brinkman

1755 ZG Petten

THE NETHERLANDS

Research Centre Rossendorf Inc.

Forschungszentrum Rossendorf

Postfach 19

Attn.: Dr. H. Funke

DO-8051 Dresden

GERMANY

Royal Institute oî Technology

Department of Nuclear Reactor Engineering

Attn.: K. M. Becker

Si-10044 Stockholm

SWEDEN

State Office for Nuclear Safety

Slezska 9

Attn.: J. Stuller

12000 Prague 2

CZECH REPUBLIC
Russian Accademy of Sciences

Nuclear Safety Institute

52, B. Tulskaya

Attn.: L. Bolshov

113191 Moscow

RUSSIA

Statens Karnkraftinspektion

P.O. Box 27106

Attn.: W. Frid

S-10252 Stockholm

SWEDEN

Swiss Federal Nuclear Safety Inspectorate

Attn.: S. Chakraborty

Ch-5232 Villigen - HSK

SWITZERLAND

UKAEA, Risley Nuclear Laboratories (4)

Risley, Warrington

Attn.: A. T. D. Butland

I. H. Dunbar

G. F. Holford

C. D. Wheatley

Cheshire WA3 4NE

UNITED KINGDOM

UKAEA, Winfrith Technology Centre (9)

Attn.:

E. J. Allen

B. R. Bowsher

T. J. Haste

N. A. Johns

S. R. Kinnersly

J. N. Lillington

A. Mason

A. J. Smethurst

D. A. Williams

Dorchester Dorset DT2 8DH

UNITED KINGDOM

University of Stuttgart (2)

IKE

Pfaffenwaldring 31

Attn.: U. Bieder

N. Kourti

D-7000 Stuttgart 80

GERMANY

VATESI

Gediminis Prospect 36

Attn.: P Vaisnys

Vilnius

LITHUANIA 
SANDIA DISTRIBUTION: (60)

MS0100 Document Processing for DOE/OSTI, 7613-2 (10)

MS0415 A. J. Grimley, 4111

MS0619 Technical Publications, 7151

MS0736 N. R. Ortiz, 6400

MS0739 K. Washington, 6429

MS0742 J. E. Kelly, 6414

MS0744 W. A. von Riesemann, 6403

MS0744 D. A. Powers, 6404

MS0745 S. L. Thompson, 6418

MS0745 R. C. Smith, 6418

MS0745 T. J. Tautges, 6418

MS0827 J. S. Rottler, 1511

MS0834 A. C. Ratzel, 1512
MS0835 R. D. Skocypec, 1513

MS0899 Technical Library, 7141 (5)

MS1137 M. D. Allen, 6422

MS1137 N. E. Bixler, 6422 (20)

MS1137 J. E. Brockmann, 6422

MS1137 R. M. Elrick, 6422

MS1137 C. M. Erickson, 6422

MS1137 T. J. Heames, 6422

MS1139 K. O. Reil, 6423

MS1139 R. C. Schmidt, 6423

MS1144 J. V. Walker, 6501

MS1145 S. A. Wright, 6514

MS1151 K. E. Boyack, 6515

MS1320 F. Gelbard, 6119

MS9211 Central Technical Files, 8523-2 

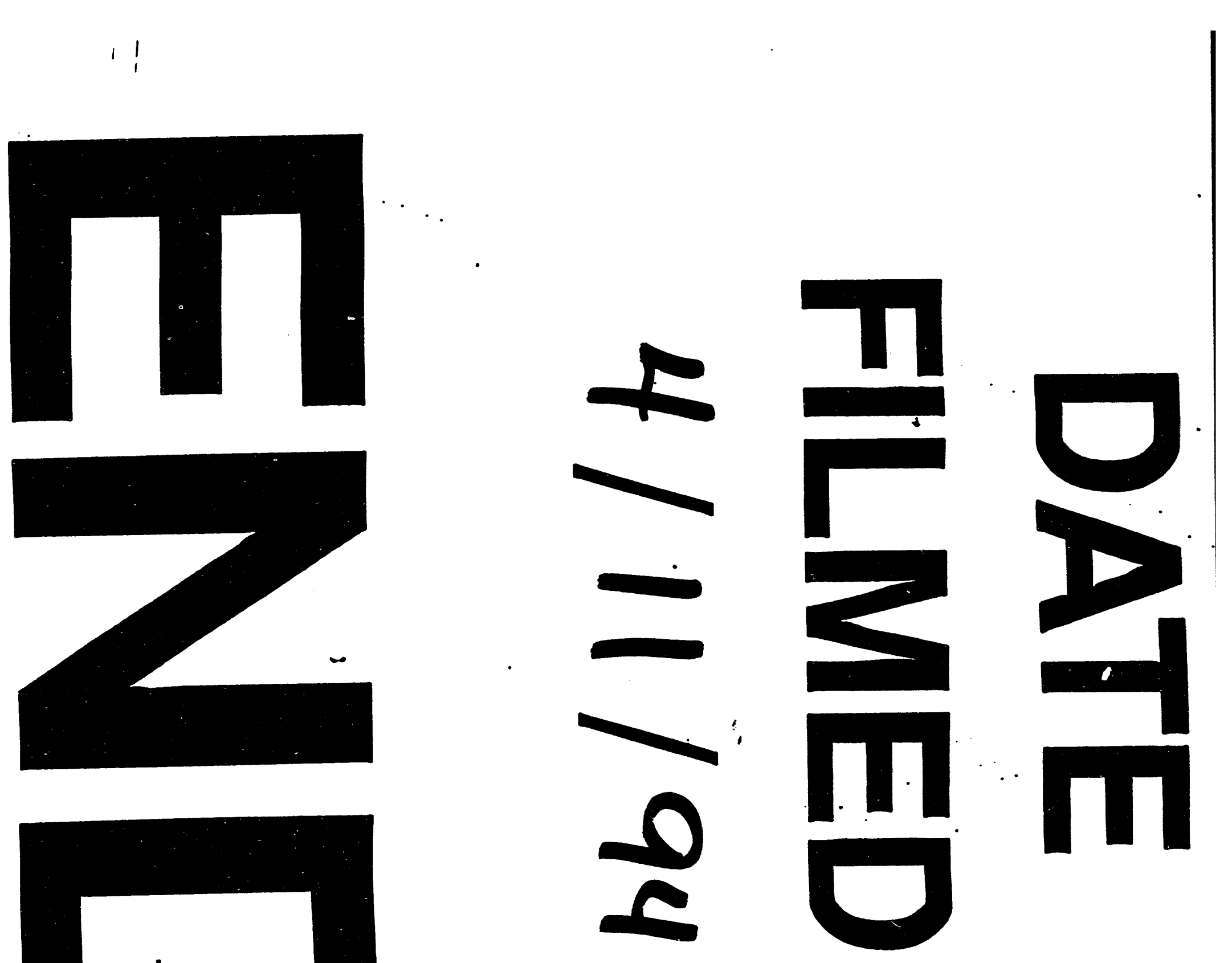